\title{
The Río de la Plata Craton: a review of units, boundaries, ages and isotopic signature
}

\author{
Pedro Oyhantçabal $\cdot$ Siegfried Siegesmund • \\ Klaus Wemmer
}

Received: 22 March 2010/Accepted: 8 July 2010/Published online: 17 August 2010

(C) The Author(s) 2010. This article is published with open access at Springerlink.com

\begin{abstract}
A review of the lithostratigraphic units in the Río de la Plata Craton and of new and previously published geochronological, isotopic and geophysical data is presented. Sm-Nd $\mathrm{T}_{\mathrm{DM}}$ model ages between 2.6 and $2.2 \mathrm{Ga}$ characterize the Piedra Alta Terrane of this craton. Crystallization ages between 2.2 and $2.1 \mathrm{Ga}$ for the metamorphic protoliths and 2.1-2.0 Ga for the post-orogenic granitoids indicate juvenile crust, followed by a short period of crustal recycling. Cratonization of this terrane occurred during the late Paleoproterozoic. Younger overprinting is not observed, suggesting it had a thick and strong lithosphere in the Neoproterozoic. A similar scenario is indicated for the Tandilia Belt of Argentina. Sm-Nd $\mathrm{T}_{\mathrm{DM}}$ model ages for the Nico Pérez Terrane show two main events of crustal growth (3.0-2.6 and 2.3-1.6 Ga). The crystallization ages on zircon ranges between 3.1 and $0.57 \mathrm{Ga}$, which is evidence for long-lived crustal reworking. The age for cratonization is still uncertain. In the Taquarembó Block, which is considered the prolongation of the Nico Pérez Terrane in southern Brazil, a similar
\end{abstract}

Electronic supplementary material The online version of this article (doi:10.1007/s00531-010-0580-8) contains supplementary material, which is available to authorized users.

P. Oyhantçabal $(\square)$

Departamento de Geología, Facultad de Ciencias,

Universidad de la República, Iguá 4225,

C.P. 11400 Montevideo, Uruguay

e-mail: oyhantca@fcien.edu.uy

S. Siegesmund $\cdot$ K. Wemmer

Geoscience Centre of the Georg-August University Göttingen,

Goldschmidtstr. 3, 37077 Göttingen, Germany

e-mail: ssieges@gwdg.de

K. Wemmer

e-mail: kwemmer@gwdg.de scenario can be observed. These differences together with contrasting geophysical signatures support the redefinition of the Río de la Plata Craton comprising only the Piedra Alta Terrane and the Tandilia Belt. The Sarandí del Yí Shear Zone is regarded as the eastern margin of this Craton.

Keywords Precambrian - Transamazonian cycle - South American platform · Río de la Plata Craton

\section{Introduction}

Almeida et al. (1973) originally defined the Río de la Plata Craton (RPC) to include the "ancient cratonic areas" of the southernmost South American Platform, "already consolidated in the upper Precambrian". Most of the RPC consists of juvenile Paleoproterozoic crust, but negative $\mathrm{Nd}$ isotopic signatures in Tandilia suggest part of the craton was mature continental crust (Cordani et al. 2000; Pankhurst et al. 2003; Peel and Preciozzi 2006; Rapela et al. 2007). Over large areas, Phanerozoic sediments cover the Craton. Rapela et al. (2007) presented U-Pb SHRIMP data for drill cores demonstrating the westward continuity of the RPC under the sedimentary cover, as far as the surroundings of the Pampean Ranges of Córdoba. The main outcrop areas of the RPC include (Fig. 1) the crystalline basement in the central to southwestern Uruguay (Dalla Salda et al. 1988), the Buenos Aires Complex of the Tandilia Belt in Argentina (Cingolani et al. 2002) and the Taquarembó block of Brazil (Hartmann 1998, Hartmann et al. 1999). A tectonostratigraphic terrane approach (Bossi and Campal 1992; Bossi et al. 1993b) takes the Sarandí del Yí Shear Zone as basis for defining two different terranes in the Río de la Plata Craton, namely the Piedra Alta Terrane in the 
Fig. 1 The main outcrop areas of the Río de la Plata Craton and the new boundary proposed in this contribution (after Preciozzi et al. 1985; Bossi and Ferrando 2001; Oyhantçabal et al. 2007b; Rapela et al. 2007; Sánchez Bettucci et al. 2010)

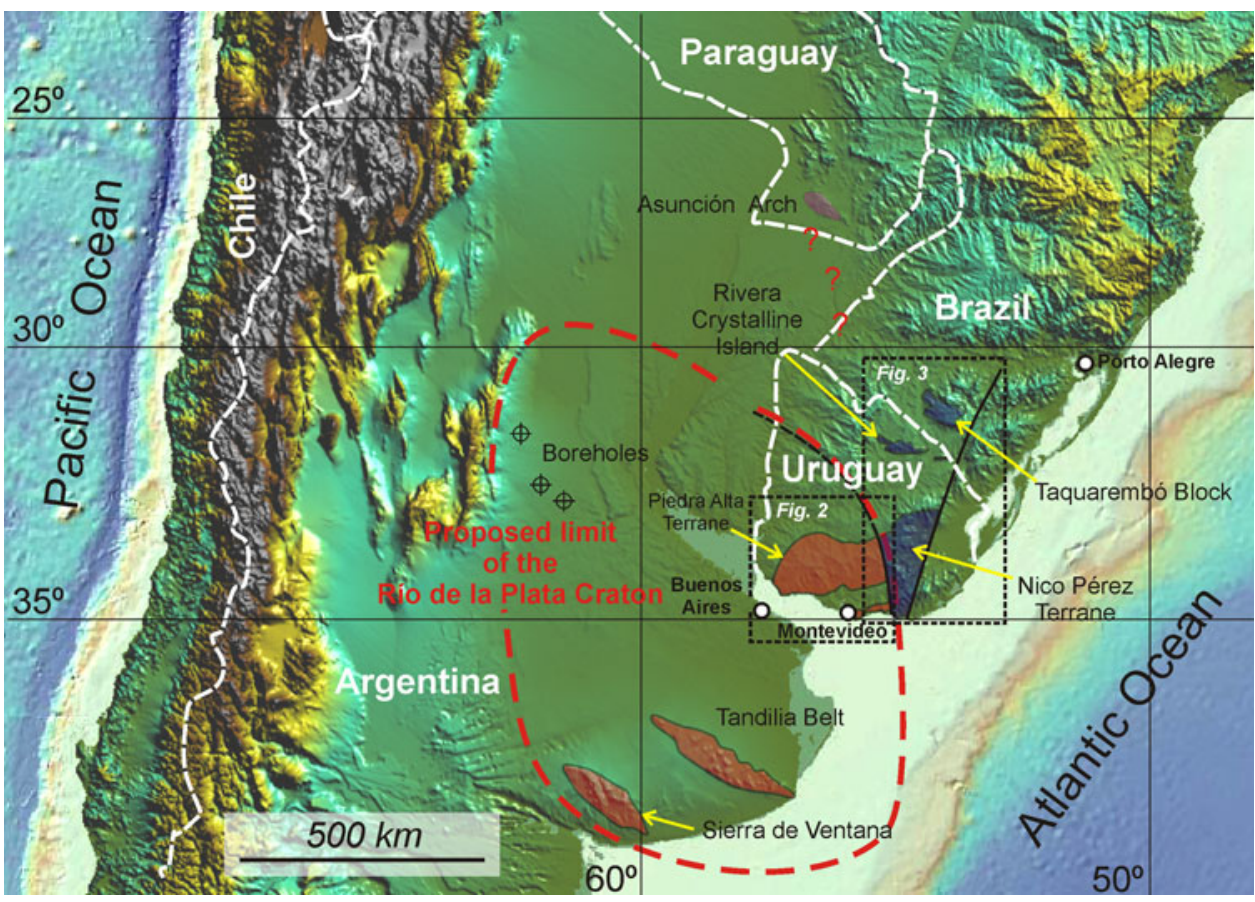

west and the Nico Pérez Terrane in the east. Only in the latter, remnants of Archean crust have been recognized (Hartmann et al. 2001). The Río de la Plata Craton is a key piece in the assembly of western Gondwana. The collision with the São Francisco/Congo and the Kalahari Cratons on its eastern margin is related to the evolution of the Dom Feliciano, Kaoko and Gariep Belts, while the collision against the Pampia Terrane on the western margin resulted in the Eastern Sierras Pampeanas. This paper reviews the recent progress in the knowledge of the craton and presents new geochronological, geochemical, $\mathrm{Sm}-\mathrm{Nd}$ and $\mathrm{Pb}$ isotope data. Utilizing this data, a new definition of the craton can be made.

\section{Geological overview of the Río de la Plata Craton}

\section{The Buenos Aires Complex of the Tandilia Belt} (Argentina)

The knowledge of the basement of Tandilia, called Buenos Aires Complex after Marchese and Di Paola (1975), has been summarized recently by Dalla Salda et al. (2006). This basement comprises granitic to tonalitic gneisses, migmatites and amphibolites. U-Pb SHRIMP ages on zircon of these gneisses yielded ages between $\sim 2.2$ and $\sim 2.1 \mathrm{Ga}$ (see Table 1). Supracrustal rocks associated with the orthogneisses include micaschists and dolomitic marbles. Delpino and Dristas (2008) estimated the peak metamorphic conditions for the marbles from Punta Tota (NE Tandilia Belt) at $750-800^{\circ} \mathrm{C}$ and $5-6 \mathrm{~kb}$ and metamorphic conditions that followed a counterclockwise $\mathrm{P}-\mathrm{T}$ trajectory suggesting extension and thinning of the crust in an intraplate setting or a marginal back-arc basin.

Granitic intrusions comprising tonalites to granites were emplaced in migmatitic gneisses (Cingolani et al. 2002). The ages of these intrusions ranges between 2.05 and 2.04 Ga (see Table 1).

Transcurrent shear zones are oriented nearly E-W, show a width up to $4 \mathrm{~km}$ and are a common feature in the Tandilia Belt. The shear-sense indicators point to dextral shearing, where a pure shear component is active during transpressive deformation (Cingolani et al. 2002 and references therein). Frisicale et al. (2007) estimated the P-T conditions at $400-450^{\circ} \mathrm{C}$ and 6 kbar during the deformation in the Azul megashear zone of Tandilia. Pankhurst et al. (2003) reported $\mathrm{Sm}-\mathrm{Nd} \mathrm{T}_{\mathrm{DM}}$ on granitoids from the Tandilia Belt ranging between 2.53 and $2.68 \mathrm{Ga}$, indicating the main period of crust formation was late Archean to Paleoproterozoic. No evidence was found, neither of younger accretion of juvenile material to the crust nor of Neoproterozoic overprinting (Cingolani et al. 2002).

\section{The Piedra Alta Terrane of southwestern Uruguay}

The Piedra Alta Terrane crops out in southwestern Uruguay and is bordered to the east by the Sarandí del Yí Shear Zone (SYSZ). The latter is the tectonic boundary with the Nico Pérez Terrane located to the east (Fig. 2).

The terrane is composed of vast granitic gneiss areas separated by supracrustal metamorphic belts. Two main belts have been recognized: (1) the San José belt (Bossi 


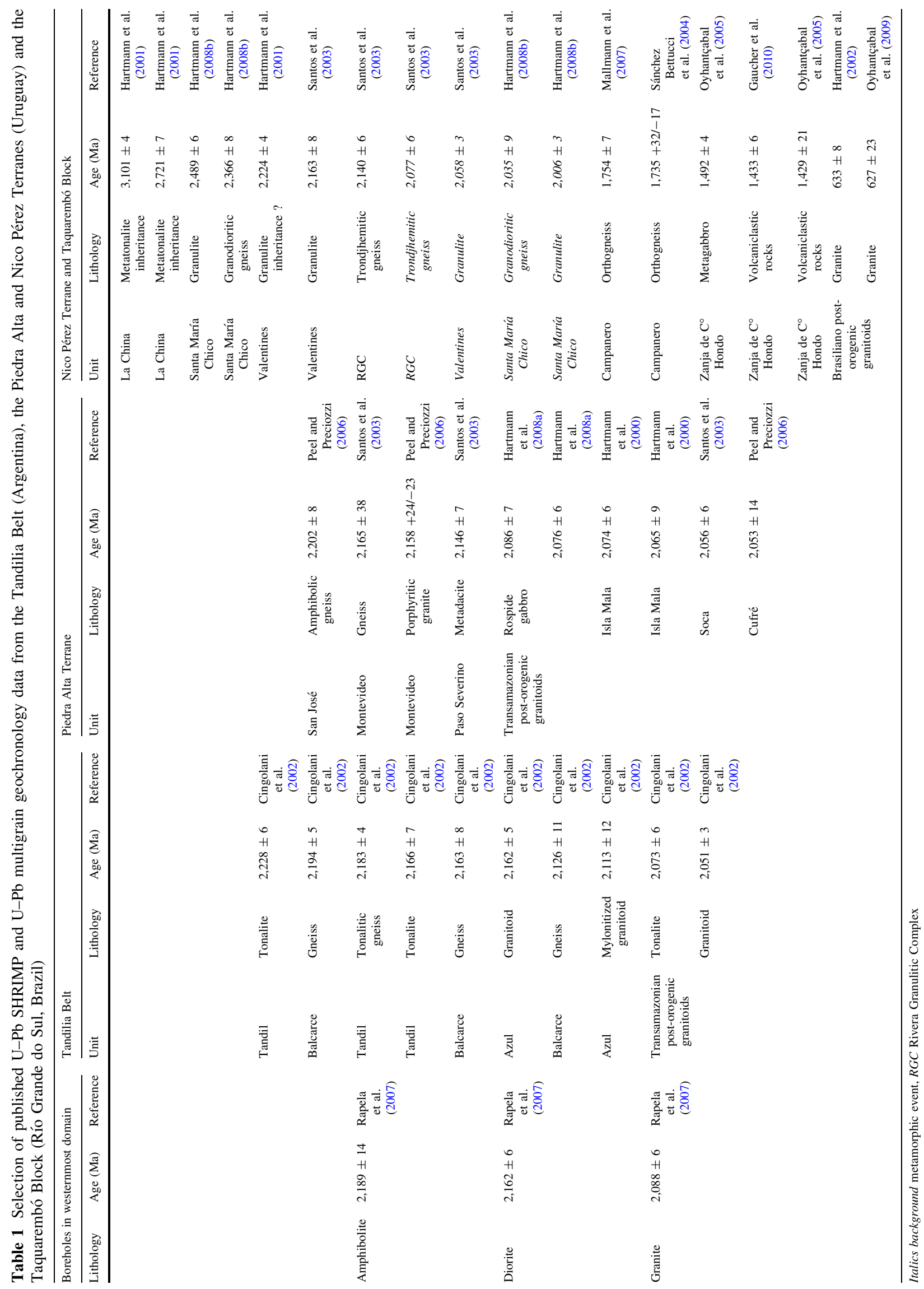


Fig. 2 Geological map of the Piedra Alta Terrane, Uruguay (after Preciozzi et al. 1985; Bossi and Ferrando 2001; Oyhantçabal et al. 2007b)

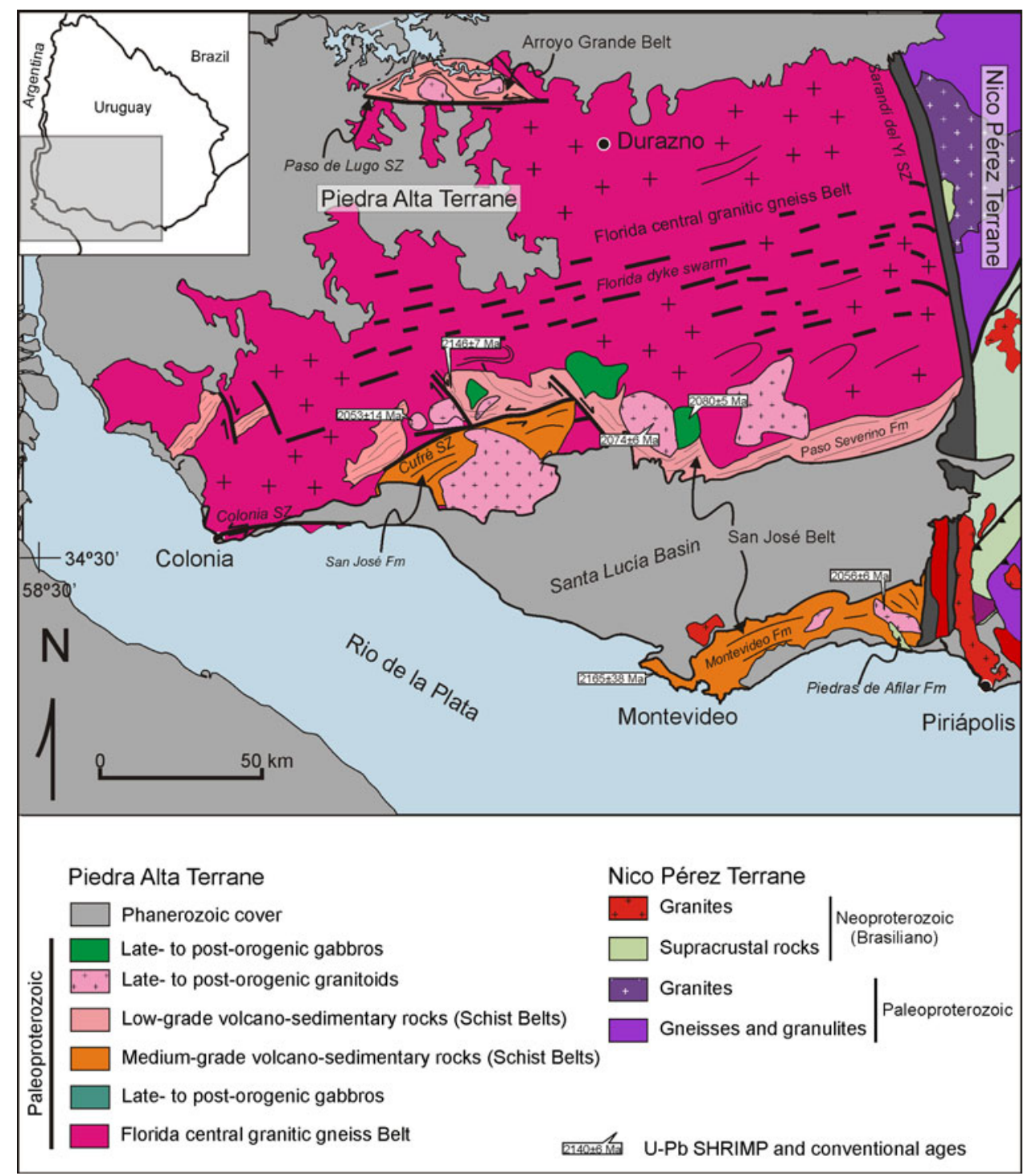

et al. 1993b; Oyhantçabal et al. 2003, 2007b; Sánchez Bettucci et al. 2010) located in southernmost Uruguay and (2) the Arroyo Grande Belt (Bossi and Ferrando 2001), which crops out in the northern part of the terrane (Fig. 2).

\section{Arroyo Grande Belt}

The Arroyo Grande Belt, about $15 \mathrm{~km}$ in width and $50 \mathrm{~km}$ in length, strikes E-W and is located at the northern edge of the exposed area of the Piedra Alta Terrane (Ferrando and Fernandez 1971; Fernandez and Preciozzi 1974; Bossi et al. 1993b; Preciozzi 1993). The belt contains the supracrustal Arroyo Grande Formation and several associated intrusive granitoids. The Arroyo Grande Formation is a greenschist facies folded volcano-sedimentary succession, with the bottom in the north and cut by the Paso de Lugo fault in the south. Siliciclastic rocks predominate in the succession and display preserved primary structures including metarenites, quartzites, metarkoses, metapelites and rarely metaconglomerates. The metavolcanic rocks are restricted to the southern zone and include metabasalts and metaandesites, with a paragenesis of chlorite, epidote, albite, quartz, opaque minerals and calcite, and metadacites. Observed mineral assemblages indicate greenschist facies metamorphism.

\section{San José Belt}

Low- to medium-grade metamorphic rocks are exposed in the basement areas flanking a Mesozoic rift (Santa Lucía Basin) in the southern Piedra Alta Terrane (Fig. 2). Originally conceived as two different metamorphic belts: Montevideo and San José (Bossi et al. 1993b) are now regarded, based on geographic proximity and similarity of structural trend and $\mathrm{U}-\mathrm{Pb}$ ages (Table 1) as belonging to a single belt interrupted by the development of a rift. The 
name San José Belt is preferred due to the better exposure in the surroundings of the City of San José (Oyhantçabal et al. 2007b).

The Montevideo Formation (Fig. 2) comprises amphibolites, paragneisses and garnet and staurolite-bearing micaschists. The San José Formation - probably the continuation of the former-is almost exclusively composed of paragneisses and garnet and staurolite-bearing micaschists (Preciozzi 1993; Oyhantçabal et al. 2003, 2007b).

The Paso Severino Formation occurs to the north of the Cufré Shear Zone and is a greenschist facies folded volcano-sedimentary succession. The formation is divided into $\mathrm{NE}$ - and NW-trending sectors, due to the influence of conjugate NNW dextral and ENE sinistral shear zones (Fig. 2).

Sedimentary lithologies include predominant metapelites and rarely dolomitic marbles and banded iron formations. The metavolcanic rocks include metabasalts and metaandesites, metadacites and metatuffs. At least two deformation events are recognized in the belt (Campal 1990; Preciozzi 1993; Oyhantçabal et al. 2007b). The last event is associated with syn-tectonic granites and the above-mentioned conjugate shear system.

$\mathrm{U}-\mathrm{Pb}$ SHRIMP ages on zircon from a metadacite of the Paso Severino Formation yielded an age of 2,146 $\pm 7 \mathrm{Ma}$ (Santos et al. 2003; see Table 1). This age matches the crystallization age of the metamorphic protoliths on a regional scale in the Río de la Plata Craton (2.22-2.1 Ga).

\section{Florida central granitic gneiss belt}

Gneisses and granites make up the bulk of the central area located between Arroyo Grande and San José Belts. Decameter- to kilometer-sized xenoliths of micaschists, paragneisses and amphibolites are common within the granites and gneisses. Several post-tectonic granites also intrude the central granitic gneiss belt. $\mathrm{U}-\mathrm{Pb}$ age determinations are not available, but $\mathrm{Rb}-\mathrm{Sr}$ whole-rock ages $(2,015 \pm 40 \mathrm{Ma}$, Piedra Alta granodiorite; 2,030 $\pm 75 \mathrm{Ma}$, Carmelo granodiorite and 1,970 $\pm 55 \mathrm{Ma}$, Conchillas granitic gneiss; Umpierre and Halpern 1971) and field relationships (Oyhantçabal et al. 2007b) indicate that the late- to postorogenic intrusions correspond to the same magmatic event responsible for the 2.08-2.05 Ga post-orogenic plutons that intruded into the Arroyo Grande and San José Belts.

\section{Paleoproterozoic late- to post-orogenic granitoids and gabbros}

Several late- and post-orogenic plutons intrude the Florida, San José and Arroyo Grande Belts. Available major element composition data summarized in Fig. 3 indicate that most of the intrusions are calc-alkaline with medium to
high-K contents, although some alkaline plutons have been also recognized. SHRIMP U-Pb ages of $2,065 \pm 9$ and $2,074 \pm 6 \mathrm{Ma}$ were obtained for the Isla Mala pluton (Hartmann et al. 2000) and 2,053 $\pm 14 \mathrm{Ma}$ (conventional multi-grain U-Pb zircon; Peel and Preciozzi 2006) for the Cufré Granite. Post-orogenic gabbros are also frequently associated (e.g. Mahoma, Rospide and Carreta Quemada Gabbros). U-Pb SHRIMP ages for zircons from the Rospide Gabbro yielded 2,076 \pm 6 and 2,086 $\pm 7 \mathrm{Ma}$ (Hartmann et al. 2008a). The similar ages of gabbros and granites point to a coeval magmatism. The Soca Granite is a unique intrusion in the Piedra Alta Terrane. It shows high contents of LIL and HFS elements and high $\mathrm{FeO}^{* /}$ $\left[\mathrm{FeO}^{*}+\mathrm{MgO}\right]$ ratios, similar to the typical rapakivi granites in southern Finland (Oyhantçabal et al. 1998), but it belongs to the A2-type post-collisional granites of Eby (1992). A SHRIMP zircon U-Pb age of 2,056 $\pm 6 \mathrm{Ma}$, reported by Santos et al. (2003), is the best estimation of the crystallization age of this granite. This confirms that the Soca Granite should not be considered an example of the typical anorogenic rapakivi association, but an A2-type rapakivi granite of the rapakivi granite-shoshonite rock series, formed after continent collision or arc magmatism (Eby 1992; Larin 2009). In summary, this late- to postorogenic association of granite and gabbro magmatism occurred at 2,080-2,050 Ma and includes medium- to high$\mathrm{K}_{2} \mathrm{O}$ calc-alkaline, alkaline and rapakivi intrusions.

\section{Florida dike swarm}

The Florida dolerite dike swarm is more than $100 \mathrm{~km}$ in width, trends c. $060^{\circ}$ and extends for more than $250 \mathrm{~km}$ from the westernmost exposed RPC in Uruguay to the Sarandí del Yí Shear Zone in the east. Individual dikes are subvertical, with a thickness attaining $50 \mathrm{~m}$ and a length up to $20 \mathrm{~km}$. Whole-rock geochemistry and petrographic features allow the distinction of high and low $\mathrm{TiO}_{2}$ tholeiitic dikes of andesitic-basalt and andesitic composition, respectively (Bossi et al. 1993a). The swarm displays positive $\varepsilon_{\mathrm{Sr}}$ and negative $\varepsilon_{\mathrm{Nd}}$ typical of an EM1type mantle source (Mazzucchelli et al. 1995). A U-Pb determination on baddeleyite of 1,790 $\pm 5 \mathrm{Ma}$ is the best estimate of the crystallization age of the high Ti dikes, considered younger than the low Ti dikes (Halls et al. 2001).

\section{Neoproterozoic volcano-sedimentary and sedimentary} successions

Neoproterozoic cover is usually lacking in the Piedra Alta Terrane, an exception is a small outcrop area corresponding to the Piedras de Afilar Formation (see Fig. 2). The formation comprises very low-grade (metamorphic?) arenites, 
Fig. $3 \mathrm{SiO}_{2}$ vs. $\mathrm{Na}_{2} \mathrm{O}+\mathrm{K}_{2} \mathrm{O}$ (a), $\mathrm{SiO}_{2}$ vs. $\mathrm{K}_{2} \mathrm{O}$ (b) and $\mathrm{R} 1-\mathrm{R} 2$ (Batchelor and Bowden 1985) diagram (c) for the Paleoproterozoic late- to postorogenic granitoids and gabbros of the Piedra Alta Terrane. Symbols blue squares Soca rapakivi granite (Oyhantçabal et al. 1998); green circles Rospide gabbro (Hartmann et al. 2008a); red circles Isla Mala, Arroyo de la Virgen, Marincho granites (Preciozzi 1993); triangles this study
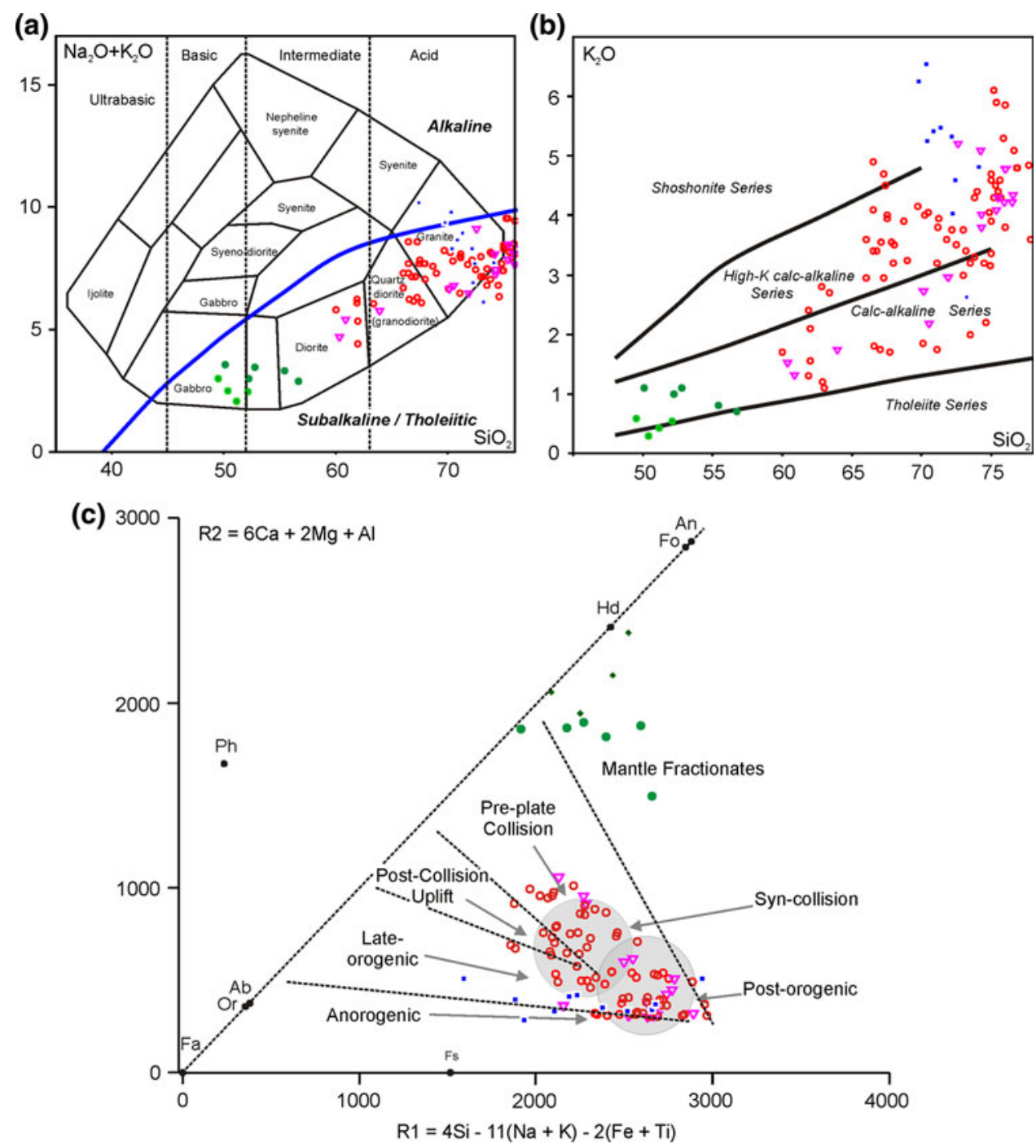

shales and limestones intruded by dolerite sills (Pecoits et al. 2008).

\section{The Nico Pérez Terrane of eastern Uruguay}

\section{Valentines-Rivera Granulitic Complex}

This complex, exposed in the northern part of the Nico Pérez Terrane, is represented by felsic to mafic granulitic orthogneisses and relicts of a platform supracrustal succession (the Vichadero Formation) including BIFs, pyroxene fels, micaschists and exceptional forsterite-bearing marbles (Ellis 1998). Mesoperthitic alkali feldspar dominates in the leucocratic orthogneisses, mostly in sub-equant grains showing triple-point junctions. Orthopyroxene and garnet is present in the mafic granulites and sillimanite and garnet in the micaschists. The felsic granulitic orthogneisses of Rivera display a high-K calc-alkaline signature compatible with a magmatic arc setting. The observed parageneses suggest a metamorphic peak at pressures of 6-9 kbar and temperatures of $\sim 800^{\circ} \mathrm{C}$ (Vidal 2009).

Santos et al. (2003) determined a crystallization U-Pb SHRIMP age of 2,140 $\pm 6 \mathrm{Ma}$ and a metamorphic age of $2,077 \pm 6 \mathrm{Ma}$ in a metatrondhjemite from Rivera. Similar $\mathrm{U}-\mathrm{Pb}$ SHRIMP ages were obtained by these authors in the granitic granulite of Valentines: $2,058 \pm 3 \mathrm{Ma}$ for the metamorphism and 2,163 \pm 8 Ma for the magmatic crystallization, but in this case some inherited older cores $(2,224 \pm 4 \mathrm{Ma})$ are observed.

Pavas Block (Preciozzi et al. 1979) La China Complex (Hartmann et al. 2001)

The Pavas Block is characterized by a predominance of mafic to ultramafic rocks associated with quartzites. Oyhantçabal and Vaz (1990) describe amphibolic gneisses, garnet amphibolites, nearly monomineralic actinolitite, interpreted as metaultramafic rocks, and fuchsite-bearing 
quartzites. An orthogneiss analyzed by Hartmann et al. (2001) showed metamorphic overgrowths on zircon that yielded U-Pb SHRIMP ages of 3.1 and $2.7 \mathrm{Ga}$, while an age of $3.41 \mathrm{Ga}$ obtained in a zircon core is considered to represent the magmatic age.

\section{Paleo- and neoproterozoic granites}

The Illescas Batholith is a large intrusive body that is cut in the west by the Sarandí del Yí Shear Zone. It is considered to be a rapakivi granite with a $\mathrm{Pb}-\mathrm{Pb}$ age of $1,784 \pm 5 \mathrm{Ma}$. Isotopic and geochemical data of this batholith are still lacking, but an A-type intrusion in an anorogenic setting is assumed (Campal and Schipilov 1995).

Neoproterozoic granites are widespread in the Nico Pérez Terrane and are related to the Brasiliano cycle. Examples for better constrained ages include the Puntas del Santa Lucía Granite (633 \pm 8 Ma; U-Pb zircon; Hartmann et al. 2002), the Puntas del Mataojo Granite (627 $\pm 23 \mathrm{Ma}$; $\mathrm{U}-\mathrm{Pb}$ on zircon; Oyhantçabal et al. 2009), the Solís de Matojo Granite, emplaced in the Sarandí del Yí Shear Zone $(584 \pm 13 \mathrm{Ma} ; \mathrm{Pb}-\mathrm{Pb}$ on sphene; Oyhantçabal et al. 2007a) and the Arroyo Mangacha Granite (583 \pm 7 ; U-Pb SIMS on zircon; Gaucher et al. 2008).

\section{Mesoproterozoic volcano-sedimentary successions}

Oyhantçabal et al. (2005) reported Mesoproterozoic ages in metavolcaniclastic rocks and gabbros associated with marbles and micaschists and erected the Zanja del Cerro Grande Group to embrace the Mesoproterozoic volcanosedimentary successions of the Nico Pérez Terrane. The supracrustals of the Zanja del Cerro Grande Group occur as tectonic slices in the gneissic basement of the Nico Pérez Terrane (Campanero Unit). For additional information about these Mesoproterozoic successions see Gaucher et al. (2010, this volume).

\section{Neoproterozoic volcano-sedimentary and sedimentary successions}

The Neoproterozoic cover is related to the evolution of the Dom Feliciano Belt and comprises a schist belt (precollisional sequences) and a foreland belt. The schist belt is not part of the Nico Pérez Terrane (see discussion below) and includes the Lavalleja Group of Uruguay and the Porongos (Rio Grande do Sul) and Brusque (Santa Catarina) Groups of southern Brazil (Basei et al. 2008a).

The foreland belt consists of several volcano-sedimentary and sedimentary successions: the Arroyo del Soldado and the Maldonado Groups (Gaucher 2000; Gaucher et al. 2003, 2004; Pecoits et al. 2004, 2008). The age is constrained by the occurrence of Ediacaran microfossils
(Gaucher et al. 2003) and U-Pb zircon dating of associated volcaniclastic rocks (Hartmann et al. 2002; Oyhantçabal et al. 2009).

Santa Maria Chico Granulitic Complex (basement of the Taquarembó block)

The basement of the Taquarembó consists of granulites and gneisses of the Santa Maria Chico Granulitic Complex. The protolith age is Paleoproterozoic $(2,366 \pm 8 \mathrm{Ma}$ and 2,489 $\pm 6 \mathrm{Ma}$; U-Pb SHRIMP; Hartmann et al. 2008b) and it was metamorphosed during the Paleoproterozoic (2.2-2.0 Ga; Hartmann 1998; Hartmann et al. 1999).

Neoproterozoic overprinting is widespread and 600550 Ma intrusions are common as in case of the Rivera Block of Uruguay (Hartmann and Nardi 1982). Felsic and mafic granulites are observed like in Uruguay, but in the case of the Santa Maria Chico Granulitic Complex, the felsic granulites show low-K calc-alkaline affinity. Geographic proximity, metamorphic style and age correlations strongly support the idea that the basement of the Taquarembó Block should be considered the prolongation of the Valentines-Rivera Granulitic Complex of Uruguay.

Basement inliers in the Dom Feliciano belt (Campanero unit and Punta del Este Terrane of eastern Uruguay; Encantadas Complex of southernmost Brazil)

\section{Campanero Unit, southernmost Uruguay}

The Campanero Unit (Fig. 4) was defined as pre-tectonic granitoids with mylonitic to gneissic texture (Sánchez Bettucci 1998). Oyhantçabal (2005) described orthogneisses, stripped orthogneisses, scapolite gneisses, amphibolites, micaschists, banded iron formations and migmatites. Major and trace element data for the orthogneiss (Oyhantçabal 2005) indicate that the protoliths are granites related to a high- $\mathrm{K}_{2} \mathrm{O}$ calc-alkaline magmatic arc. Mallmann et al. (2007) reported a U-Pb SHRIMP determination on zircon that yielded a concordant age of $1,754 \pm 7 \mathrm{Ma}$, interpreted as the age of the magmatic crystallization of the protolith. A similar age, 1,735 $+32 /-17 \mathrm{Ma}$, but using the conventional U-Pb systematic was found by Sánchez Bettucci et al. (2004). It is remarkable that the roughly coeval Illescas Rapakivi Granite corresponds to an anorogenic setting that did not experience high-grade metamorphism, suggesting both units were allochthonous in the Paleoproterozoic. Amphibole from an amphibolite of the Campanero Unit yielded a weighted average age of plateau-like fractions of $564 \pm 4.1 \mathrm{Ma}$ (Oyhantçabal et al. 2009), which constrain the Ediacaran cooling history (at c. $500^{\circ} \mathrm{C}$ ) of this unit. 
Fig. 4 Geological map of the Nico Pérez Terrane and the contiguous Dom Feliciano Belt (after Preciozzi et al. 1985; Bossi and Ferrando 2001;

Mallmann et al. 2007; Sánchez Bettucci et al. 2010)

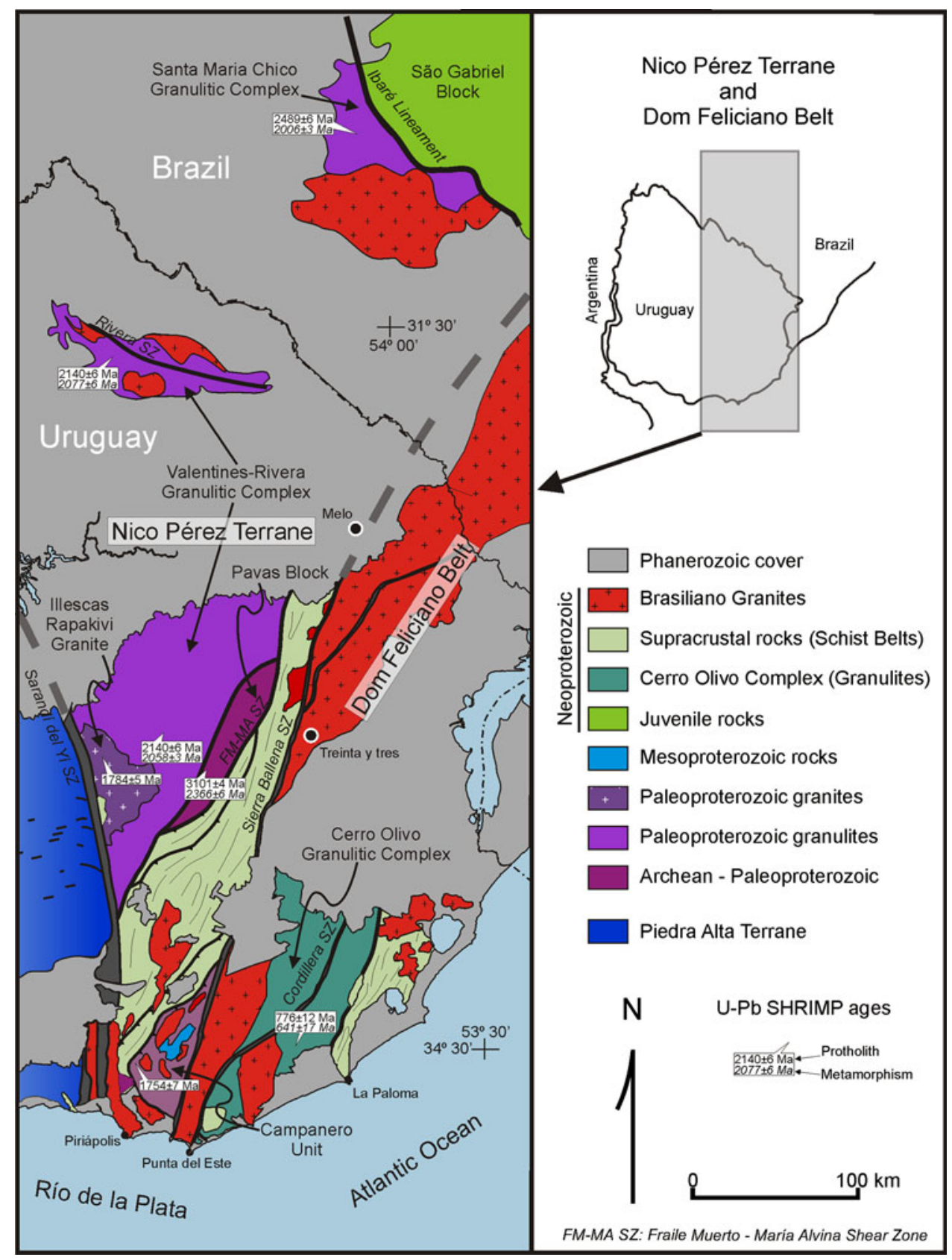

\section{The Punta del Este Terrane of eastern Uruguay}

The Punta del Este Terrane, located east of the Sierra Ballena Shear Zone (Preciozzi et al. 1999) and considered a pre-Brasiliano basement (Fig. 3), comprises orthogneisses, paragneisses, amphibolites and migmatites of the Cerro Olivo Complex (Masquelin 2004). Conditions for the metamorphic peak are estimated at temperatures ranging between $770^{\circ}$ and $850^{\circ} \mathrm{C}$ and pressures between 7 and 11 kbar (Masquelin et al. 2001). Magmatic ages at 850-750 Ma on zircon and high-temperature metamorphism dated at 650-600 Ma confirm the correlation between the Punta del Este Terrane and the Coastal Terrane of the Kaoko Belt (Oyhantçabal et al. 2009; Gross et al. 2009). Similar ages have also been reported in xenoliths of the Pelotas Batholith (da Silva et al. 1999) and in the Neoproterozoic basement of the Brusque Group $(843 \pm 12 \mathrm{Ma}$, U-Pb SHRIMP on zircon; Basei et al. 2008b).

\section{Encantadas complex, southernmost Brazil}

The Encantadas Complex (not shown in Fig. 4; for details see Saalmann et al. 2010, this volume) comprises 
Paleoproterozoic gneisses of tonalitic and trondhjemitic composition and minor associated amphibolites and metaultramafic rocks and extends in Rio Grande do Sul from Pinheiro Machado in the southeast to Porto Alegre in the northeast (Hartmann et al. 2003; Philipp et al. 2008). Saalmann et al. (2010, this volume) discuss the possibility that the Porongos Schist Belt and Pelotas Batholith belong to a tectonic unit (Encantadas microcontinent) which was later amalgamated to the Rio de la Plata Craton and the São Gabriel Block.

\section{Geophysics}

Gravity data acquisition in Uruguay was undertaken during the last 50 years by the Military Geographic Service and the Geological Survey (DINAMIGE). A dataset of Bouguer anomalies with fairly good spatial coverage (2,566 measurements; ca $1 / 70 \mathrm{~km}^{2}$ ) is available from DINAMIGE. The isostatic residual Bouguer anomaly map of Uruguay is shown in Fig. 5. Gravity signature confirms most structural features of the Precambrian Basement of Uruguay. The Piedra Alta Terrane shows E-W oriented gravity highs matching the San José and Arroyo Grande supracrustal belts. The Sarandí del Yí Shear Zone coincides with a lowgravity lineament, whose prolongation can be traced with NW trend to Argentina. In eastern Uruguay, the gravity signature is characterized by a c. N-S trend, in concordance with the structure of the southern Dom Feliciano Belt and a roughly E-W gravity high related to the Mesozoic Laguna Merín Basin (Fig. 5).
Hallinan et al. (1993) presented the first revision of the structure of the southern Brazilian Shield based on gravity and magnetic data and concluded that gravity data do not support the prolongation of the Río de la Plata Craton into Brazil and that "....any linkage between Nico Perez Terrane and the Rio de la Plata Craton is necessarily speculative, if more detailed investigations are not available, such as petrographic and geochronological studies." The isostatic residual Bouguer anomaly map presented in Fig. 5 confirms the conclusions of these authors.

\section{U-Pb geochronology}

Selected U-Pb ages, most of them SHRIMP ages on zircon, from the basement of the Río de la Plata Craton are presented in Table 1. Crystallization ages of protoliths range between 2.1 and $2.22 \mathrm{Ga}$ in the Tandilia Belt, in the Piedra Alta Terrane and in the westernmost boreholes where the basement is not exposed. Late- to post-orogenic igneous activity at $2.0-2.1 \mathrm{Ga}$ is also observed in these units.

Data in the Nico Pérez Terrane and in the Taquarembó Block reflect a protracted history: inherited zircon ages range from 3.41 to $2.2 \mathrm{Ga}$ and are a sign of long-lived crustal recycling processes. Furthermore, high-grade metamorphism is recorded in zircon overgrowths that yielded U-Pb SHRIMP ages of 2.1-2.0 Ga.

These data suggest different tectonic settings at 2.0-2.1 Ga in the Nico Pérez Terrane and the Taquarembó Block, where high-grade peak metamorphism and deformation occurred, compared to the rest of the Río de la Plata

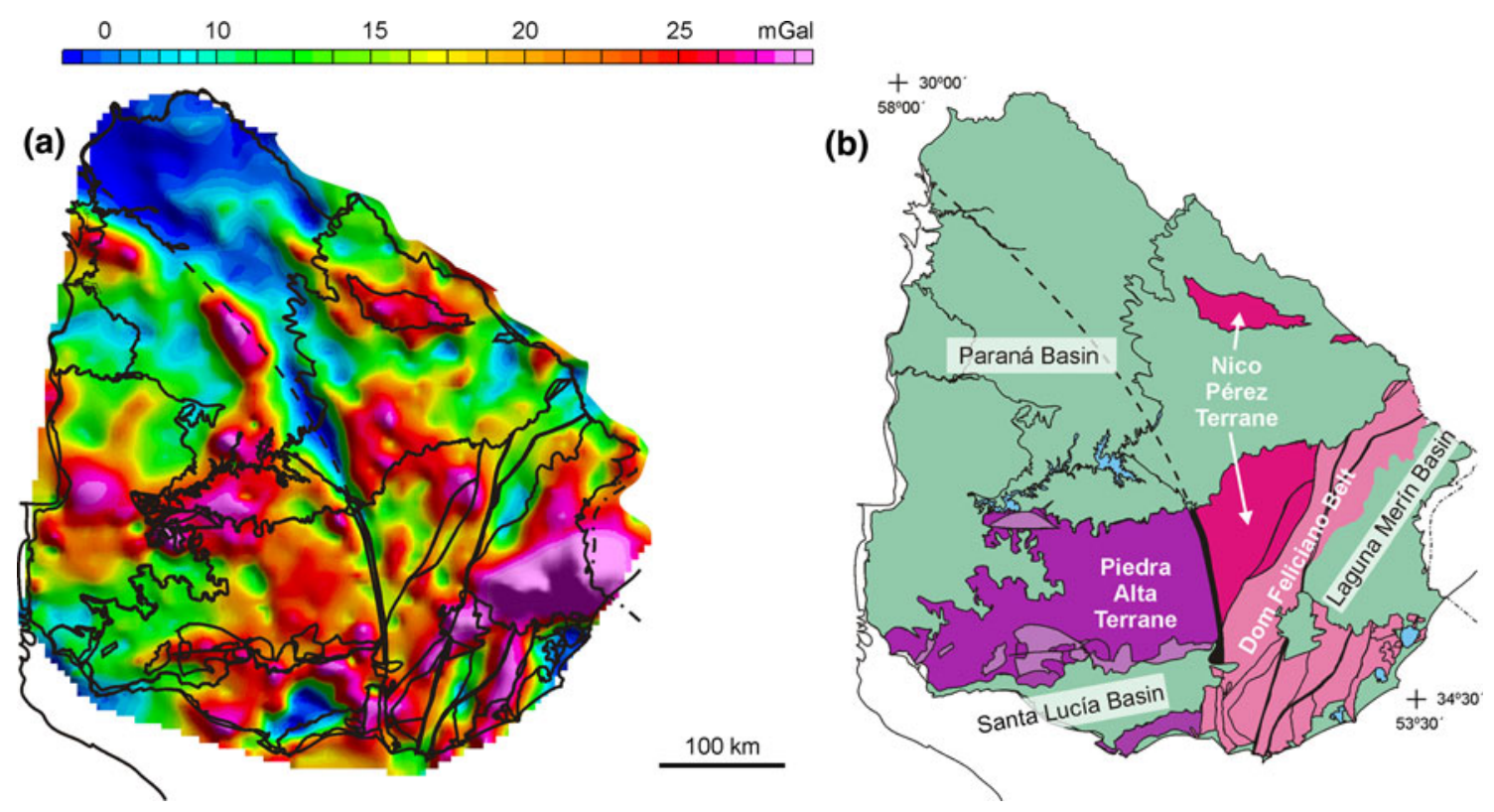

Fig. 5 a Isostatic residual gravity map of Uruguay showing the main geological boundaries. b Geologic sketch map of Uruguay showing the major geological divisions (redrawn after Sanchez Bettucci and Oyhantcabal 2008) 
Craton, where late- to post-orogenic events took place. In addition, calc-alkaline arc-related magmatism at c. $1.7 \mathrm{Ga}$ (orthogneiss of the Campanero Unit) and Mesoproterozoic volcano-sedimentary rocks occur exclusively in the Nico Pérez Terrane.

In accordance with the original definition of Almeida et al. (1973), the Río de la Plata Craton was "already consolidated in the upper Precambrian". Excluding the Nico Pérez Terrane, not finally cratonized until the Phanerozoic, the Río de la Plata Craton is characterized by two tectonothermal Transamazonian events at 2.2-2.1 and 2.1-2.05 Ga, which can be correlated with the second and third Transamazonian orogenies of Santos et al. (2003). These data suggest the Nico Pérez Terrane could be considered an allochthonous terrane, which was accreted to the Río de la Plata Craton since at least Neoproterozoic time. Constraints on accretion age are discussed below.

\section{Sm-Nd isotope data}

Thirteen samples of metasedimentary and igneous rocks from the crystalline basement of Uruguay were analyzed (analytical data and location of the samples are available in the electronic appendix) and model ages calculated. Samples were selected in order to cover the different basement units of Uruguay including the Piedra Alta Terrane (4 samples), the Nico Pérez Terrane (5 samples) and the Punta del Este Terrane (4 samples). The latter, located in the easternmost part of Uruguay, is a basement unit related to the Dom Feliciano Belt and probably of African affinity (Oyhantçabal et al. 2009; Gross et al. 2009).

The Piedra Alta Terrane shows $\mathrm{T}_{\mathrm{DM}}$ crustal residence times between 2.28 and $1.76 \mathrm{Ga}$ (mean $2.03 \mathrm{Ga}, n=4$ ); in the Nico Pérez Terrane, $\mathrm{T}_{\mathrm{DM}}$ ages varies between 2.72 and $1.86 \mathrm{Ga}$ and finally in the Punta del Este Terrane values between 2.19 and $1.44 \mathrm{Ga}$ (mean $=1.82 \mathrm{Ga}, n=4$ ) were found.

For more statistical significance, these new data are analyzed together with those previously published for the Río de la Plata Craton (Fig. 6). The Tandilia Belt (24 samples) and the Piedra Alta Terrane (16 samples) show quite similar histograms, where most of the values are clustered between 2.7 and $2.2 \mathrm{Ga}$. $\mathrm{T}_{\mathrm{DM}}$ ages in the Piedra Alta Terrane seems to be slightly younger, but the difference is not statistically significant. The younger $\mathrm{T}_{\mathrm{DM}}$ ages, 1.92 and $1.76 \mathrm{Ga}$, were obtained in Neoproterozoic sediments of the Piedras de Afilar Formation, for this reason some contribution from a source in the adjacent Nico Pérez Terrene or the Dom Feliciano Belt is expected and confirmed by previously published U-Pb ages of detrital zircons (Gaucher et al. 2008). This similarity in crustal residence times, together with the above-mentioned
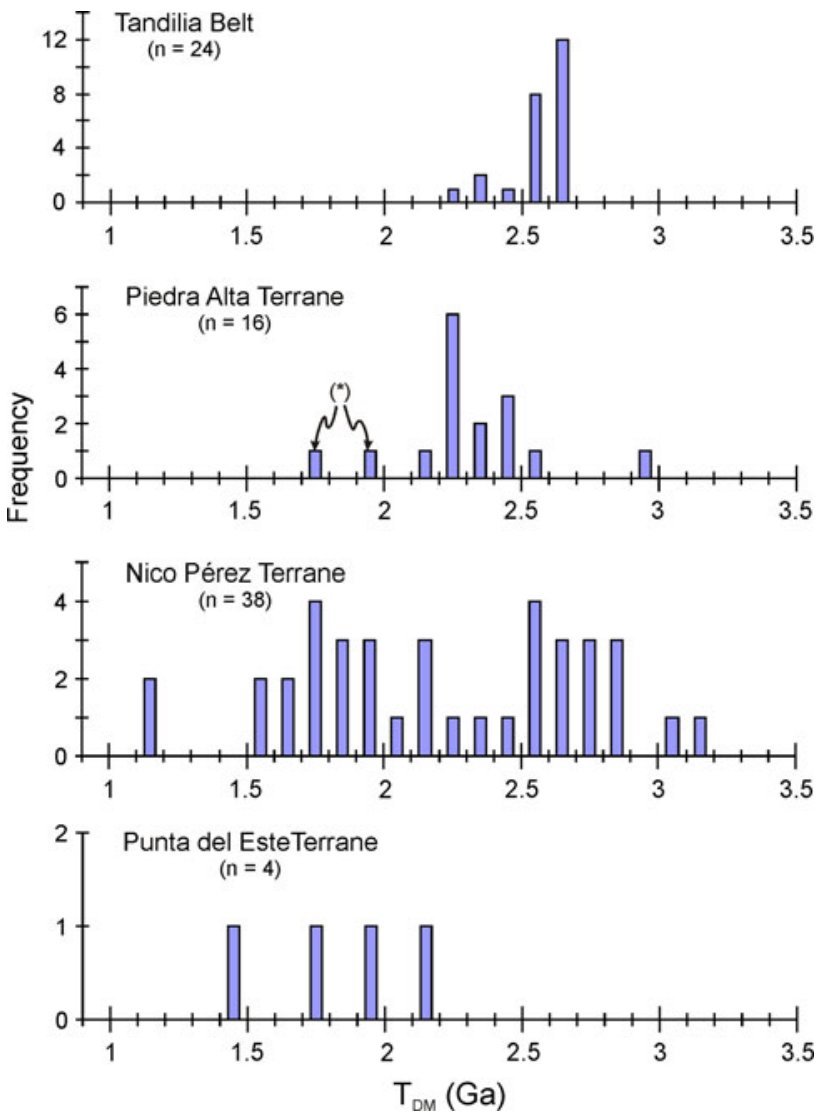

Fig. 6 Histograms of $\mathrm{Sm}-\mathrm{Nd} \mathrm{T}_{\mathrm{DM}}$ model ages for the different terranes of the Río de la Plata Craton and the Dom Feliciano Belt in Uruguay. Asterisk Neoproterozoic Piedras de Afilar formation, some contribution from a source in the adjacent Nico Pérez Terrene or the Dom Felicano Belt is expected

similarity in $\mathrm{U}-\mathrm{Pb}$ geochronology indicates that the Tandilia Belt and the Piedra Alta Terrane are not allochthonous, and rather rule out the hypothesis of Bossi and Cingolani (2009).

The Nico Pérez Terrane presents a bi-modal distribution of $\mathrm{T}_{\mathrm{DM}}$ ages: one cluster at $3.0-2.6 \mathrm{Ga}$ and the other at 2.3-1.6 Ga. This is consistent with the wide range of $\mathrm{U}-\mathrm{Pb}$ ages and indicates two main events of crustal extraction from the mantle. $\mathrm{T}_{\mathrm{DM}}$ ages for the analyzed samples of the Punta del Este Terrane range between 2.19 and $1.44 \mathrm{Ga}$. The pattern looks similar to the younger cluster of the Nico Pérez Terrane, but the data are not sufficient to draw any conclusion.

\section{Preliminary whole-rock $\mathbf{P b}-\mathbf{P b}$ data}

$\mathrm{Pb}$ isotopic signatures have been used to discriminate between different basement domains (Schwartz and Gromet 2004; Drobe et al. 2009). Six samples of metasedimentary rocks from the crystalline basement of Uruguay 
Fig. 7 a ${ }^{208} \mathrm{~Pb} /{ }^{204} \mathrm{~Pb}$ versus

${ }^{205} \mathrm{~Pb} /{ }^{204} \mathrm{~Pb}$ diagram. Fields for the different basement domains are taken from Tosdal (1996) and Schwartz and Gromet (2004). b ${ }^{207} \mathrm{~Pb} /{ }^{204} \mathrm{~Pb}$ versus ${ }^{206} \mathrm{~Pb} /{ }^{204} \mathrm{~Pb}$ domains of South America after Aitcheson et al. (1995), Kay et al. (1996), Loewy et al. (2003, 2004 and references therein)
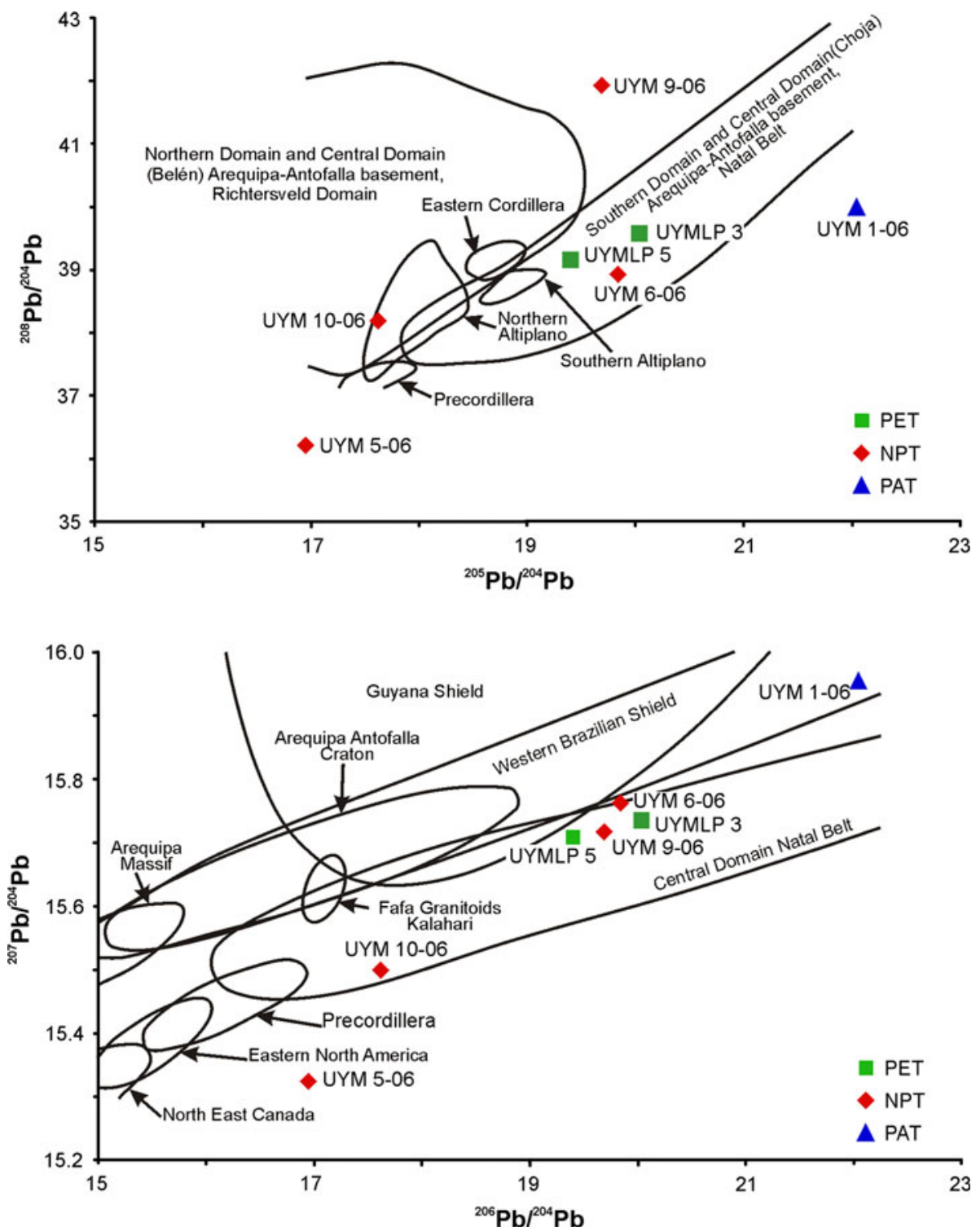

were analyzed. Results and location of the samples are presented as an electronic appendix. All samples are metasedimentary rocks, one from the Piedra Alta Terrane, four from the Nico Pérez Terrane and two from the Punta del Este Terrane. Most of the samples plot in a near linear array that overlaps the different compositional fields defined for western Gondwana (Fig. 7). Samples from Nico Pérez and Punta del Este Terranes plot very close to one another, suggesting a similar reservoir and the possibility that both terranes are not allochthonous, but other criteria discard this correlation (see discussion below). The sample from the Piedra Alta Terrane (UYM 1-06) displays higher ${ }^{207} \mathrm{~Pb} /{ }^{204} \mathrm{~Pb}$ and ${ }^{206} \mathrm{~Pb} /{ }^{204} \mathrm{~Pb}$ ratios than all the other samples. It plots in the ${ }^{208} \mathrm{~Pb} /{ }^{204} \mathrm{~Pb}$ versus ${ }^{205} \mathrm{~Pb} /{ }^{204} \mathrm{~Pb}$ diagram outside the linear trend defined by the other samples. Additional data are necessary in order to allow the definition of allochthonous blocks based on $\mathrm{Pb}$ isotopic data.

\section{Muscovite K-Ar age constraints on tectonothermal events}

Nineteen muscovite samples, along a transect across the major tectonic units of the Río de la Plata Craton (Piedra Alta Terrane and Nico Pérez Terrane) and the Dom Feliciano Belt in southern Uruguay, were selected for $\mathrm{K}-\mathrm{Ar}$ isotopic analysis to constrain the timing of the medium temperature (350 to $420^{\circ} \mathrm{C}$ ) cooling history. Analytical results are shown in the electronic appendix.

The $\mathrm{K}-\mathrm{Ar}$ cooling ages provide time constraints for the exhumation and cooling in the Piedra Alta Terrane between 2,057 and 1,796 Ma and demonstrate that this terrane was not thermally overprinted during Meso- or Neoproterozoic times (Fig. 8). Neoproterozoic cooling ages (628-545 Ma) characterize the basement domains located east of the Sarandí del Yí Shear Zone (Nico Pérez Terrane and the 


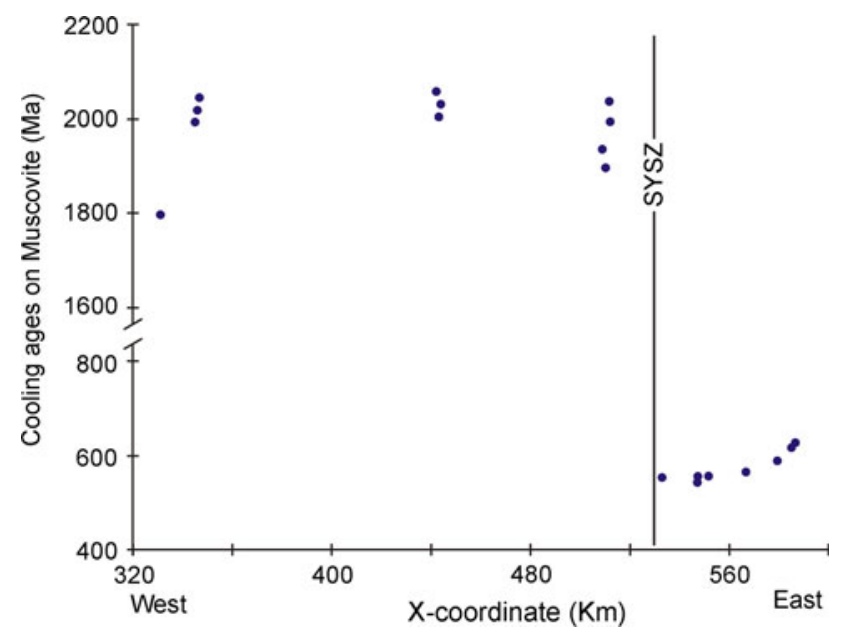

Fig. 8 Time-space diagram of muscovite $\mathrm{K}-\mathrm{Ar}$ cooling ages across the Piedra Alta Terrane, the Nico Pérez Terrane and the Dom Feliciano Belt (east-west profile). X coordinates in kilometers. Origin of coordinates $55^{\circ} 48^{\prime} \mathrm{W}$

Dom Feliciano Belt), which is in agreement with the geological evidence of widespread Neoproterozoic reworking.

The Ediacaran Piedras de Afilar Formation in the Piedra Alta Terrane, containing Mesoproterozoic detrital zircons (Gaucher et al. 2008), provides proof that the Piedra Alta and Nico Pérez Terranes were juxtaposed prior to the Ediacaran. Nevertheless, it is remarkable that no Ediacaran overprinting is observed in the $\mathrm{K}-\mathrm{Ar}$ isotopic system, even in the easternmost outcrops sampled in the Piedra Alta Terrane, although they are less than $25 \mathrm{~km}$ away from the Sarandí del Yí Shear Zone. Furthermore, cooling ages change abruptly from Paleoproterozoic in the Piedra Alta Terrane to Neoproterozoic in the Nico Pérez Terrane. These findings are consistent with the results of Teixeira et al. (1999) showing ${ }^{40} \mathrm{Ar}-{ }^{39} \mathrm{Ar}$ plateau ages of 2,016 $\pm 11 \mathrm{Ma}$ (hornblende) and 1,817 \pm $10 \mathrm{Ma}$ (biotite) in a post-tectonic granodiorite from the Piedra Alta Terrane, and $596 \pm 5$ (hornblende) and $563 \pm 4 \mathrm{Ma}$ (biotite) in a granodiorite from the Nico Pérez Terrane.

\section{Discussion}

Magmatic and metamorphic events and isotopic signatures

The tectonostratigraphic chart of Fig. 9 shows the age of the main events on the different terranes and domains of the Río de la Plata Craton and the contiguous Dom Feliciano Belt. The Piedra Alta Terrane is characterized by magmatic events at $2.2-2.1 \mathrm{Ga}$ (age of the protolith magmatism) and at 2.1-2.0 Ga (late- to post-orogenic granitoids and gabbros). The metamorphism is therefore constrained between both magmatic events. $\mathrm{T}_{\mathrm{DM}}$ model ages span between 2.8 and $2.3 \mathrm{Ga}$, indicating remnants of older continental crust contributing to the magma. $\mathrm{K}-\mathrm{Ar}$ cooling ages on muscovite point out cratonization at $1.7-1.8 \mathrm{Ga}$ and that this terrane remained unaffected by younger tectonothermal events. A similar scenario is observed in the case of the Tandilia Belt. Available isotopic data do not support the hypothesis that the Tandilia Terrane is an allochthonous unit as suggested by Bossi et al. (2005).

The histogram of $\mathrm{T}_{\mathrm{DM}}$ model ages of the Nico Pérez Terrane shows two main events of crustal growth (3.0-2.6 and 2.3-1.6 Ga), consistent with U-Pb zircon ages showing long-lived crustal recycling processes (Oyhantçabal et al. 2009). U-Pb geochronology indicates magmatic events at 3.1 to $2.5 \mathrm{Ga}$ (age of the protolith magmatism), and high-T metamorphism at $2.08-2.05 \mathrm{Ga}$ (felsic and mafic granulites). A similar scenario is observed in the Santa María Chico Granulitic Complex, and therefore we suggest that the Taquarembó Block of Río Grande do Sul is part of the Nico Pérez Terrane. Granites showing a Brasiliano age, which are subduction-related as well as posttectonic, are widespread in the Nico Pérez Terrane and in the Taquarembó Block.

\section{Proterozoic mafic dike swarms}

Table 2 summarizes the available petrological and geochronological data of the Precambrian dike swarms of the Río de la Plata Craton. A calc-alkaline dike swarm intruded near-coeval with the post-orogenic granitic plutonism, which stands out in the Tandilia (Teixeira et al. 2002). In the Nico Pérez Terrane of Uruguay, a dike swarm of similar age has not been recognized yet, but numerous gabbro intrusions, like Mahoma, Rospide and Carreta Quemada, could represent this event of mafic post-orogenic magmatism.

Iacumin et al. (2001) underlined the geochemical similarities between the tholeiitic Florida dike swarm in the Piedra Alta Terrane $(1.79 \mathrm{Ga})$ and the tholeiitic dikes of Tandilia ( $1.59 \mathrm{Ga}$, Teixeira et al. 2002; more precise age determinations are still lacking). Both dike swarms are probably coeval and may correspond to anorogenic extension roughly $200 \mathrm{Ma}$ after the Transamazonian orogeny in the Río de la Plata Carton (Teixeira et al. 2002). In the Nico Perez Terrane, the Illescas Granite $(1.79 \mathrm{Ga})$ is the only known example of pre-Neoproterozoic anorogenic magmatism. Extensional anorogenic events at 1.75-1.68 Ga are well recorded in most of the cratons of the Brazilian shield (see Table 13 in Teixeira et al. 1999). In contrast, Neoproterozoic dike swarms have only been identified in the Nico Pérez Terrane (Table 2). 
Fig. 9 Tectonostratigraphic chart of the Piedra Alta and Nico Pérez Terranes and the Dom Feliciano Belt in Uruguay

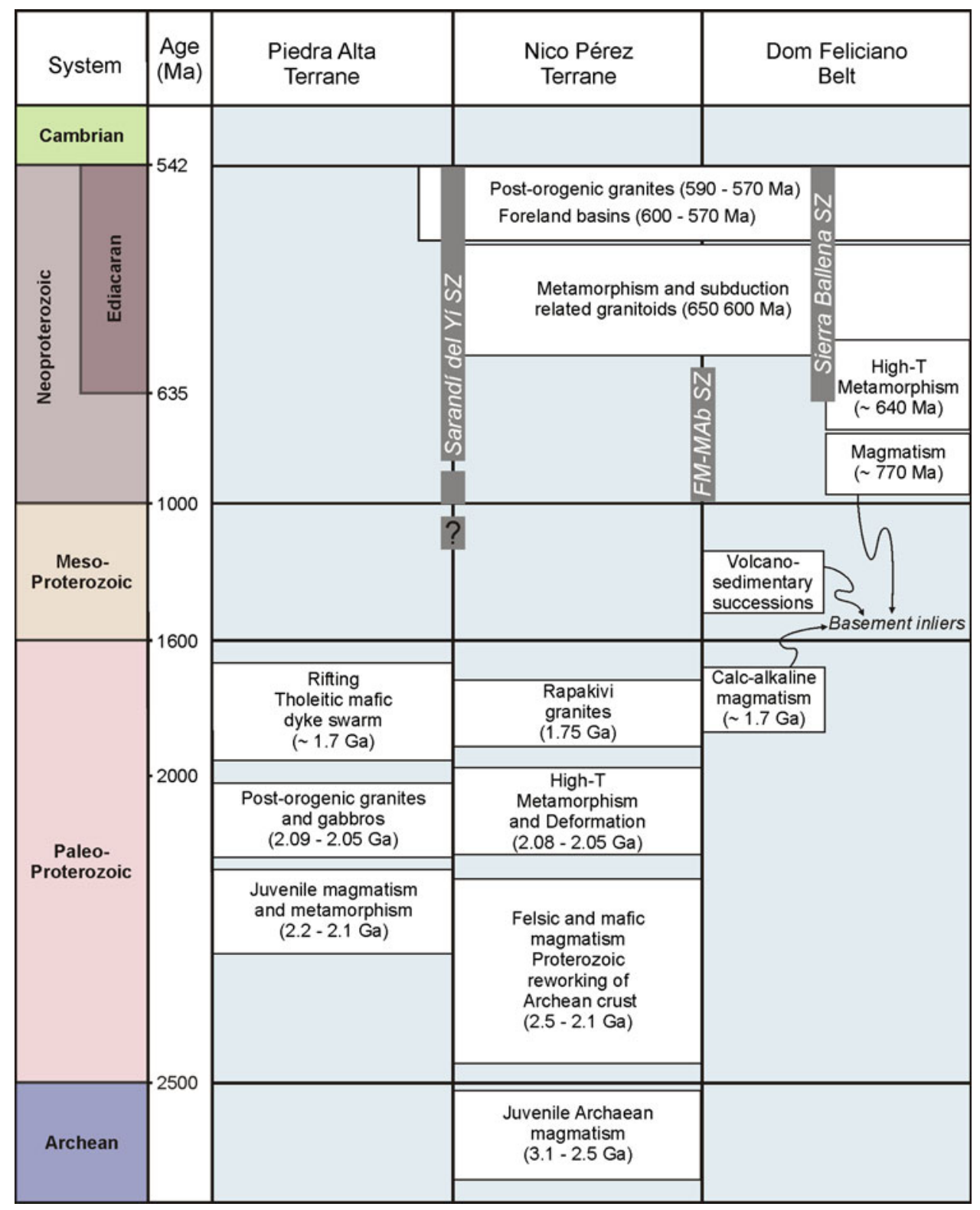

Redefinition of the boundaries and internal structure of the RPC

\section{The Piedra Alta Terrane and a redefinition of the Rio de la Plata Craton}

The definition of the boundaries of the Río de la Plata Craton depends on how a craton is defined. After the extraction of basaltic magmas from the mantle, continents can build a buoyant and refractory mantle lithosphere stagnant to subduction and to deformation (Sengör 1999; Slepp 2005). If a continent with such a lithosphere is left untouched more than $1 \mathrm{Ga}$, cooling will make it very strong. Nowadays a craton is defined as a "core region of a continent that has remained stable on a billion-year $(\mathrm{Ga})$ time scale" (Hoffman 1988; Eaton et al. 2009). Alkmim (2004) defines cratons as differentiated components of the continental lithosphere that are provided with thick, cold, old and buoyant mantle roots, and as a consequence a high lithospheric strength that avoids pervasive deformation.

A sharp contrast in behavior, in relation to tectonothermal Brasiliano events, is observed between the Piedra Alta Terrane and the Nico Pérez Terrane. The Piedra Alta Terrane is not affected by tectonic or thermal Neoproterozoic Brasiliano orogenic events. In contrast, the Nico Pérez Terrane as well as the Taquarembó Block show Neoproterozoic widespread reworking, including granitic intrusions, shear zones and foreland deposits.

These pieces of evidence indicate cratonization of the Piedra Alta Terrane occurred at Paleoproterozoic times and 


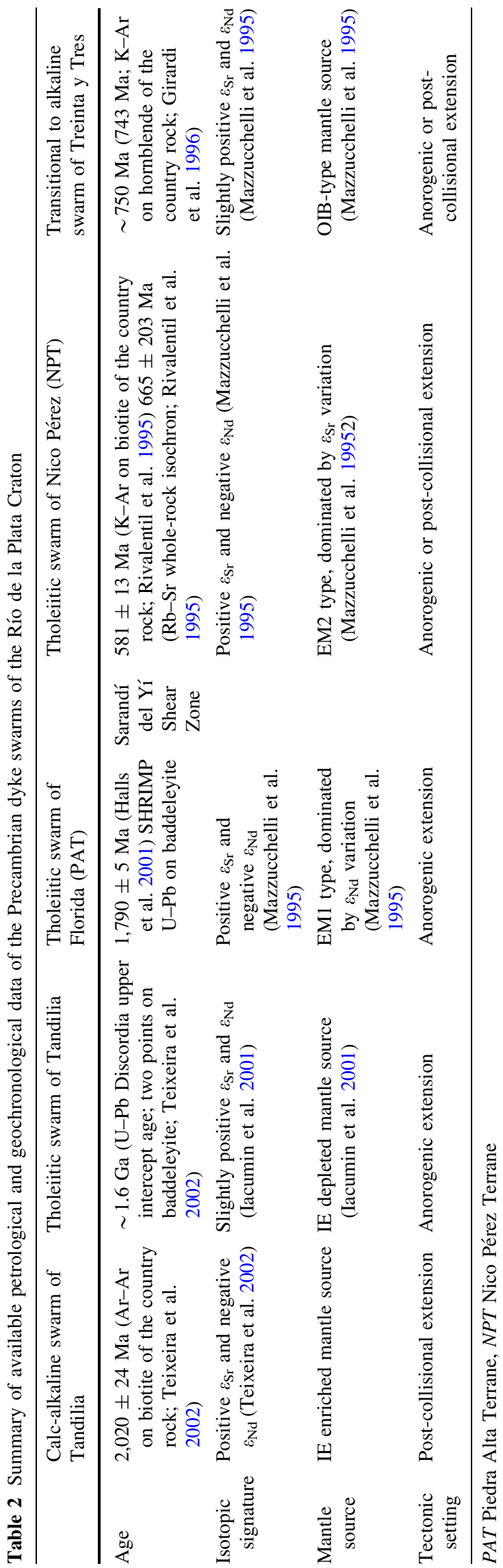

that already in the Precambrian this terrane developed a thick lithosphere, probably after the extensional episode related to the Florida dike swarm $(\sim 1.79 \mathrm{Ga}) .{ }^{40} \mathrm{Ar}-{ }^{39} \mathrm{Ar}$ plateau ages on hornblende $(1,727 \pm 10 \mathrm{Ma})$ and biotite $(1,725 \pm 10 \mathrm{Ma})$ from this dike swarm, obtained by Teixeira et al. (1999), confirm that they intruded into a cold crust. In contrast, the Nico Pérez Terrane was not endowed with a thick and strong lithosphere during Brasiliano events and was therefore strongly reworked. Lithospheric thicknesses in the present-day crust is probably similar in both terranes, but the geological record indicates that this was probably very different during the Neoproterozoic. Despite the occurrence of older continental crust surviving in the Nico Pérez Terrane and in the Taquarembó Block, repeated tectonothermal events probably prevent cratonization (Fig. 9).

An alternative hypothesis that may explain the different degree of observed Neoproterozoic reworking includes the Paleoproterozoic stretching of the crust during widespread extensional events at 1.7-1.8 Ga, which is observed in both terranes. This could have resulted in slices of thinned continental crust being later re-amalgamated. However, the following pieces of evidence rule out this alternative hypothesis, and therefore the terranes should be considered exotic:

- Lack of Eo-, Paleo- or Mesoarchean crust-forming events in the Piedra Alta Terrane

- High-temperature regional metamorphism and foliation development in granulites of the Valentines-Rivera and Santa María Chico complexes at 2.08-2.05 Ga is coeval with post-orogenic granites in Piedra Alta Terrane and Tandilia (2.09-2.05 Ga) and calc-alkaline unmetamorphosed dikes in Tandilia.

- Extension at 1.8-1.7 Ga occurred in both terranes, but extension of this age is a common feature of all cratons and blocks of the South American Platform (Teixeira et al. 1999).

- Mesoproterozoic supracrustal successions only occur in the basement inliers of the Dom Feliciano Belt (as discussed in the literature and considered a part of the Nico Pérez Terrane; Bossi and Cingolani 2009) and are lacking in the Piedra Alta Terrane and Tandilia.

- Lack of Neoproterozoic reworking in the Piedra Alta Terrane, but widespread granitic intrusions, shear zones and $\mathrm{K}-\mathrm{Ar}-\mathrm{Ar}-\mathrm{Ar}$ thermal resetting of this age in the Nico Pérez terrane.

The main question that arises is when both terranes were accreted. There is an abundance of Mesoproterozoic detrital zircons in quartz arenites of the Ediacaran Piedras de Afilar Formation from the Piedra Alta Terrane (Gaucher et al. 2008), where no Mesoproterozoic source areas occur, and indicate that both terranes were already accreted in Ediacaran times. Emplacement of the syntectonic Solís de 
Mataojo Granitic Complex in the Sarandí del Yí Shear Zone at $584 \pm 13 \mathrm{Ma}$ (Oyhantçabal et al. 2007a) also confirms a pre-Ediacaran age of accretion.

Bossi and Cingolani (2009) suggested that the Sarandí del Yí Shear Zone records dextral shearing at 1,200-1,250 Ma, based on a $\mathrm{K}-\mathrm{Ar}$ age on muscovite from a pegmatite in a thrust plane. Using this data as the age for accretion is quite speculative. First, this age determination is in a thrust plane, more than $10 \mathrm{~km}$ away (see Fig. 2 in Gaucher et al. 2010, this volume), and not in the transcurrent shear itself. Additionally, there is still lack of detailed information indicating if thrusting is pre-, syn- or post-transcurrent shear zone. Secondly, deformation conditions in the Sarandí del Yí Shear Zone, with evidence of incipient feldspar recrystallization, indicate temperatures in the range $550-450^{\circ} \mathrm{C}$ (Oyhantçabal et al. 2010), and therefore this age could represent, at best, only a cooling age. On the other hand, the radical difference in behavior with respect to the Brasiliano Orogeny points out that accretion of both terranes did not occur over a long time before this event; otherwise, the lithospheric thickness and strength would be more similar in both terranes. An examination of the tectonostratigraphic chart (Fig. 9) indicates that the accretion age is poorly constrained, at best between 1.75 and $0.6 \mathrm{Ga}$, and that the possibility of an accretion during the Neoproterozoic should not be excluded. The abovementioned arguments indicate that the Río de la Plata Craton does not include the Nico Pérez Terrane and that the Sarandí del Yí Shear Zone is the eastern boundary of the craton.

\section{The Nico Pérez Terrane, the Taquarembó Block and the basement inliers in the Dom Feliciano Belt}

The medium- to high-grade basement units located east of the Sarandí del Yí Shear Zone have undergone a quite complex geological evolution, and different authors have assumed different definitions and models. Archean to Paleoproterozoic rocks crop out, but Neoproterozoic reworking is widespread (Figs. 4 and 9). The record of the Neoproterozoic Brasiliano Orogeny includes volcanosedimentary successions, shear zones and granitoids (Campal and Schipilov 1999; Mallmann et al. 2007; Bossi and Cingolani 2009 and Sánchez Bettucci et al. 2010). Some units, for instance the Campanero Unit, are discussed in terms of basement inliers of the Dom Feliciano Belt or part of the Nico Pérez Terrane, depending on whether the Sierra Ballena Shear Zone or the Fraile Muerto-María Albina Shear Zone is regarded as the eastern boundary of the Nico Pérez Terrane (Bossi and Cingolani 2009; Sánchez Bettucci et al. 2010). Furthermore, the relationship between the pre-Brasiliano basement on the eastern side of the Sierra Ballena and the Nico Pérez Terrane is still not clear.

Preciozzi et al. (1979) originally recognized the Valentines Block between the Sarandí del Yí and the Fraile
Muerto-Maria Albina shear zones (Sánchez Bettucci et al. 2010). Bossi and Campal (1992) later defined the Nico Pérez Terrane, to include all units located between the Sarandí del Yí Shear Zone and the Sierra Ballena Shear Zone. According to Hartmann et al. (2001), the Nico Pérez Terrane includes the Valentines Complex, the La China Complex, the Las Tetas Complex, the Fuente del Puma Formation and the Arroyo del Soldado Group. In this contribution, we agree with Preciozzi et al. (1979) and Sánchez Bettucci et al. (2010) and consider the Fraile Muerto-Maria Albina Shear Zone as the eastern boundary of the Nico Pérez Terrane. Regarding the lithostratigraphic similarity between the Valentines-Rivera Granulitic Complex and the Santa Maria Chico Granulitic Complex of the Taquarembó Block, we propose the continuation of the Nico Pérez Terrane until the Ibaré Lineament in Río Grande do Sul. This lineament represents the contact with the juvenile Neoproterozoic Sao Gabriel Block (Saalmann et al. 2005).

The affinity of the basement inliers in the Dom Feliciano Belt in Uruguay (Campanero Unit and the Cerro Olivo Complex $=$ Basement of the Punta del Este Terrane) is still unclear due to the scarcity of data. The same holds true for the basement of the Dom Feliciano Belt in Río Grande do Sul. The so-called Encantadas Complex represents the pre-Brasiliano basement of the Porongos Group and the Pelotas Batholith (Saalmann et al. 2010, this volume). The possibility arises, that all these basement inliers were part of the Encantadas microcontinent (see Saalmann et al. 2010, this volume). On the other hand, available data indicate that the Nico Pérez Terrane and the Taquarembó Block were not part of the Encantadas microcontinent: the c. $1.75 \mathrm{Ga}$ calc-alkaline magmatism of the Campanero Unit is different from the roughly coeval 1.75 Ga rapakivi Illescas Granite; additionally, magmatism at $\sim 770 \mathrm{Ma}$ and metamorphism at $640 \mathrm{Ma}$ is recorded only in the Dom Feliciano Belt. A separate pre-650 Ma evolution is therefore more realistic (see Saalmann et al. 2010, this volume).

\section{Conclusions}

A review of lithostratigraphic units in the Río de la Plata Craton, new and previously published geochronological, isotopic data and gravity signatures reveal the following main conclusions:

1. The Piedra Alta Terrane is characterized by a single event of crustal growth with $\mathrm{Sm}-\mathrm{Nd} \mathrm{T}_{\mathrm{DM}}$ model ages between 2.8 and $2.3 \mathrm{Ga}$. Crystallization ages of 2.2-2.1 Ga for the metamorphic protoliths and 2.1-2.05 Ga for the granitoids indicate juvenile crust and a short period of crustal recycling. Cratonization, as revealed from $\mathrm{K}-\mathrm{Ar}$ and $\mathrm{Ar}-\mathrm{Ar}$ geochronology, 
occurred at Paleoproterozoic times (Statherian) and a lack of Meso- or Neoproterozoic overprinting is a distinctive feature, pointing out that this terrane already had a thick and strong lithosphere in the Neoproterozoic. A similar scenario is indicated for the Tandilia Belt of Argentina.

2. The histogram of Sm-Nd $\mathrm{T}_{\mathrm{DM}}$ model ages for the Nico Pérez Terrane shows two events of crustal growth (3.0-2.6 Ga and 2.3-1.6 Ga). Crystallization ages on zircon show ages between 3.1 and $0.57 \mathrm{Ga}$, which is evidence that the continental crust was reworked during several events in the Paleo-, Meso- and Neoproterozoic. A cratonization age cannot be defined, and Neoproterozoic overprinting, expressed in the granites, shear zones and folded supracrustals, is extensive. A similar scenario is observed in the Taquarembó Block, which is considered the prolongation of the Nico Pérez Terrane in southern Brazil.

3. The difference in gravity signatures observed in the residual Bouguer gravity map reinforce the lack of affinity between the Piedra Alta and Nico Pérez terranes.

4. The basement inliers of the Dom Feliciano Belt (Campanero Unit and Encantadas Complex) seems to record a pre-Brasiliano geological history different from those of Piedra Alta and Nico Pérez terranes, but further investigation is required.

5. The above-mentioned differences between the Piedra Alta Terrane and the Tandilia Belt on the one hand, and the Nico Pérez Terrane and the Taquarembó Block on the other, support the redefinition of the Río de la Plata Craton comprising the Piedra Alta Terrane of Uruguay and the Tandilia Belt of Argentina. The Sarandí del Yí Shear Zone is regarded as the eastern margin of this craton.

Acknowledgments The authors thank K. Simon (Abt. Geochemie, GZG Göttingen) and R. Naumann (GFZ Potsdam) for geochemical analyses and Robert Frei (Institute of Geography and Geology, University of Copenhagen) for $\mathrm{Pb}-\mathrm{Pb}$ isotopic determinations. We like to thank Kerstin Saalmann and Augusto Rapalini for rigorous and constructive reviews.

Open Access This article is distributed under the terms of the Creative Commons Attribution Noncommercial License which permits any noncommercial use, distribution, and reproduction in any medium, provided the original author(s) and source are credited.

\section{Appendix}

Analytical techniques

For geochemical and isotope geochemical whole-rock analyses, the sample material was crushed following standard techniques using a jaw crusher and an agate mill. Major elements were analyzed at the Geoforschungszentrum (GFZ) in Potsdam using a Panalytical XRF-PW 2400.

\section{$\mathrm{K}-\mathrm{Ar}$ dating of muscovite samples}

Mica separation was performed by the standard techniques such as crushing, sieving, Frantz magnetic separation and selection by hand. The pure micas were ground in alcohol and sieved to remove altered rims, which might have suffered argon loss. The argon isotopic composition was measured in a Pyrex glass extraction and purification line coupled to a VG $1200 \mathrm{C}$ noble gas mass spectrometer operating in static mode. The amount of radiogenic ${ }^{40} \mathrm{Ar}$ was determined by the isotopic dilution method using a highly enriched ${ }^{38} \mathrm{Ar}$ spike from Schumacher, Bern (Schumacher 1975). The spike is calibrated against the biotite standard HD-B1 (Fuhrmann et al. 1987). The age calculations are based on the constants recommended by the IUGS quoted in Steiger and Jaeger (1977). Potassium was determined in duplicate by flame photometry using an Eppendorf Elex 63/61. The samples were dissolved in a mixture of $\mathrm{Hf}$ and $\mathrm{HNO}_{3}$ according to the technique of Heinrichs and Herrmann (1990). $\mathrm{CsCl}$ and $\mathrm{LiCl}$ were added as an ionization buffer and internal standard, respectively. The analytical error for the $\mathrm{K}-\mathrm{Ar}$ age calculations has a $95 \%$ confidence level of $2 \sigma$. The procedural details for argon and potassium analyses at the laboratory in Göttingen are given in Wemmer (1991).

\section{$\mathrm{Sm}-\mathrm{Nd}$ isotope data}

$\mathrm{Nd}$ and $\mathrm{Sm}$ isotopic analyses were performed on representative samples by conventional isotope dilution technique. The samples were weighed into Teflon vials and spiked with a suitable amount of ${ }^{150} \mathrm{Nd}-{ }^{149} \mathrm{Sm}$ spike solution prior to dissolution in a mixture of $2 \mathrm{ml} \mathrm{HF}$ and $1 \mathrm{ml} \mathrm{HNO}_{3}$ with a PicoTraceTM digestion system. The solutions were processed by standard cation-exchange techniques for purification of the $\mathrm{Sm}$ and $\mathrm{Nd}$ fractions. For the determination of isotopic compositions, $\mathrm{Sm}$ and $\mathrm{Nd}$ were loaded with $2.5 \mathrm{~N} \mathrm{HCl}$ on pre-conditioned double Re filaments. Measurements of isotopic ratios were performed on a Finnigan Triton thermal ionization mass spectrometer (TIMS) measuring in static mode (GZG, Department of Isotope Geology). Repeated measurement of the $\mathrm{Nd}$ in-house standard yielded a ${ }^{143} \mathrm{Nd} /{ }^{144} \mathrm{Nd}$ ratio of $0.511798 \pm 0.000077$ ( $n=71,2 \mathrm{r}$ ) over the course of this study. The obtained $\mathrm{Nd}$ isotopic ratios of the samples were normalized to a ${ }^{146} \mathrm{Nd} /{ }^{144} \mathrm{Nd}$ ratio of 0.7219 . Total procedure blanks were consistently below $150 \mathrm{pg}$ for $\mathrm{Sm}$ and Nd. All ${ }^{143} \mathrm{Nd} /{ }^{144} \mathrm{Nd}$ ratios are reported with their $2 \mathrm{r}$ internal precision plus the uncertainties resulting from the 
spike correction. The data were calculated according to the model of Goldstein et al. (1984).

$\mathrm{Pb}$ isotopic data

Rock powders were pre-treated with $\mathrm{HBr}$, dissolved with $\mathrm{HF}$ and $\mathrm{HNO}_{3}$ during addition of $\mathrm{HBO}_{3}$ (Connelly et al. 2006), and then dried and redissolved in $\mathrm{HNO}_{3}$. $\mathrm{Pb}$ isotope ratios of whole rocks were analyzed at the Institute of Geography and Geology, University of Copenhagen, using a VG Sector 54 IT mass spectrometer. Chemical separation of $\mathrm{Pb}$ was performed over conventional anion exchange columns with $\mathrm{HBr}-\mathrm{HCl}$, followed by purification on 200-ml Teflon columns. Fractionation of $\mathrm{Pb}$ during static multicollection-mode mass-spectrometric analysis was monitored by repeated analysis of the NBS 981 standard (Todt et al. 1993) and amounted to $0.105 \pm 0.008 \%$ per atomic mass unit (amu; $n=12,2 \sigma$ ). Procedural $\mathrm{Pb}$ blanks remained below $50 \mathrm{pg}$; this low blank does not affect the measured $\mathrm{Pb}$ isotopic ratios of the samples significantly.

\section{References}

Aitcheson S, Harmon RS, Moorbath S, Schneider A, Soler P, SoriaEscalante E, Steele G, Swainbank I, Wörner G (1995) Pb isotopes define basement domains of the altiplano, central Andes. Geology 23:555-558

Alkmim FF (2004) O que faz de um cráton um cráton? O Cráton do São Francisco e as revelações almeidianas ao delimitá-lo. In: Mantesso-Neto V, Bartorelli A, Carneiro CDR, Brito-Neves BB (eds) Geologia do Continente Sul-Amricano: Evolução da Obra de Fernando Flávio de Almeida. BECA, Auckland, pp 17-36

Almeida FFM, Amaral G, Cordani UG, Kawashita K (1973) The Precambrian evolution of the South American cratonic margin, South of Amazonas River. In: Nairn ACM, Kanes WH, Stehli FG (eds) The Ocean Basins and Margins. Plenum, New York, pp 411-446

Basei MAS, Frimmel HE, Nutman AP, Preciozzi F (2008a) West Gondwana amalgamation based on detrital zircon ages from Neoproterozoic Ribeira and Dom Feliciano belts of South America and comparison with coeval sequences from SW Africa. In: Pankhurst RJ, Trouw RAJ, Brito Neves BB, De Wit MJ (eds) West Gondwana: pre-cenozoic correlations across the south Atlantic region. Geological Society, London, pp 294, 239-256 (special publications)

Basei MAS, Nutman A, Grasso CB, Vlach S, Siga Jr O, Osako L (2008b) The cryogenian rift-related granitogenesis of the Dom Feliciano Belt, Southern Brazil. In: Abstracts volume, 4th international SHRIMP workshop, Saint Petersburg, Russia. VSEGEI Press, St. Peterburg, pp 24-26

Batchelor RA, Bowden P (1985) Petrogenetic interpretation of granitoid rock series using multicationic parameters. Chem Geol 48:43-56

Bossi J, Campal N (1992) Magmatismo y tectónica transcurrente durante el Paleozoico inferior del Uruguay. In: Gutiérrez J, Saavedra J, Rábano I (eds) Paleozoico Inferior de IberoAmérica. Universidad de Extremadura, Alicante, pp 343356
Bossi J, Cingolani C (2009) Extension and general evolution of the Río de la Plata Craton. In: Gaucher C, Sial AN, Halverson GP, Frimmel HE (eds) Neoproterozoic-Cambrian tectonics, global change and evolution: a focus on southwestern Gondwana. Developments in precambrian geology, vol 16. Elsevier, Amsterdam, pp 73-85

Bossi J, Ferrando L (2001) Carta geológica del Uruguay. Geoeditores. CD-ROM, Montevideo

Bossi J, Campal N, Civetta L, Demarchi G, Girardi V, Mazzucchelli M, Negrini L, Rivalenti G, Fragoso Cesar A, Sinigoi S, Texexeira W, Piccirillo E, Molesini M (1993a) Early Proterozoic dike swarms from western Uruguay: geochemistry, $\mathrm{Sr}-\mathrm{Nd}$ isotopes and petrogenesis. Chem Geol 106:263-277

Bossi J, Preciozzi F, Campal N (1993b) Predevoniano del Uruguay. Parte 1: Terreno Piedra Alta. DINAMIGE, Montevideo, pp 1-50

Bossi J, Pineyro D, Cingolani CA (2005) El límite sur del Terreno Piedra Alta (Uruguay). Importancia de la faja milonítica sinistral de Colonia. Actas XVI Congreso Geológico Argentino $1: 173-180$

Campal N (1990) Aportes al conocimiento de la estratigrafía durante el Precámbrico medio del Uruguay (con énfasis en los departamentos de Florida y San José). In: $1^{\circ}$ Congreso Uruguayo de Geología. Resúmenes Ampliados 1. Montevideo, Uruguay, pp 65-69

Campal N, Schipilov A (1995) The Illescas bluish quartz rapakivi granite (Uruguay-South America): some geological features. In: Symposium Rapakivi granites and related rocks. Belém, Brazil, p 18

Campal N, Schipilov A (1999) The eastern edge of the Rio de la Plata Craton: a history of tangential collisions. Basement Tectonics 13:33-48

Cingolani CA, Hartmann LA, Santos JOS, y McNaughton NJ (2002) $\mathrm{U}-\mathrm{Pb}$ SHRIMP dating of zircons from the Buenos Aires Complex of the Tandilia Belt, Río de la Plata Craton, Argentina. XV Congreso Geológico Argentino, Actas 1:149-154

Connelly J, Thrane K, Krawiec A, Garde A (2006) Linking the Palaeoproterozoic Nagssugtoqidian and Rinkian orogens through the Disko Bugt region of West Greenland. J Geol Soc London 163:319-335

Cordani UG, Sato K, Teixeira W, Tassinari CCG, Basei MAS (2000) Crustal evolution of the South American platform. In: Cordani UG, Milani EJ, Thomaz-Filho A, Campos DA (eds) Tectonic evolution of South America. International Geological Congress, Río de Janeiro, pp 19-40

da Silva LC, Hartmann LA, McNaughton NJ, Fletcher IR (1999) SHRIMP U-Pb zircon Dating of Neoproterozoic Granitic Magmatism and Collision in the Pelotas Batholith, southernmost Brazil. Int Geol Rev 41:531-551

Dalla Salda L, Bossi J, Cingolani CA (1988) The Río de la Plata Cratonic Region of Southwestern Gondwanaland. Episodes 11:263-269

Dalla Salda L, Spalletti L, Poiré D, De Barrio R, Echeveste H, Enialgo A (2006) Tandilia. INSUGEO, Serie Correlación Geológica 21:17-46

Delpino SH, Dristas JA (2008) Dolomitic marbles and associated calc-silicates, Tandilia belt, Argentina: Geothermobarometry, metamorphic evolution, and P-T path. J SA Earth Sci 25:501-525

Drobe M, López de Luchi MG, Steenken A, Frei R, Naumann R, Siegesmund S, Wemmer K (2009) Provenance of the late Proterozoic to early Cambrian metaclastic sediments of the Sierra de San Luis (Eastern Sierras Pampeanas) and Cordillera Oriental, Argentina. J SA Earth Sci 28:239-262

Eaton DW, Darbyshire F, Evans RL, Grütter H, Jones AG, Yuan X (2009) The elusive lithosphere-asthenosphere boundary (LAB) beneath cratons. Lithos 109:1-22 
Eby GN (1992) Chemical subdivision of the A-type granitoids: petrogenetic and tectonic implications. Geology 20:641-644

Ellis J (1998) The precambrian supracrustal rocks of the Isla Cristalina de Rivera in northern Uruguay and their ore deposits. Heidelberger Geowissenschaftliche Abhandlungen 90, $195 \mathrm{p}$

Fernandez AN, Preciozzi F (1974) La formación Arroyo. Grande y los granitoides asociados. In: Annales. XXVIII Congreso. Brasileiro de Geologia pp 212-226

Ferrando L, Fernandez A (1971) Esquema tectónico-cronoestatigráfico del predevoniano en Uruguay. In: XXV Congreso Brasilero de Geología, vol 1. San Pablo, Paulo, pp 199-210

Frisicale MC, Martinez FJ, Dimieri LV, Dristas JA (2007) Microstructural analysis and P-T conditions of the Azul megashear zone, Tandilia, Buenos Aires province, Argentina. J SA Earth Sci 19:433-444

Fuhrmann U, Lippolt HJ, Hess JC (1987) Examination of some proposed $\mathrm{K}-\mathrm{Ar}$ standards: $40 \mathrm{Ar} / 39 \mathrm{Ar}$ analyses and conventional K-Ar-Data. Chem Geol 66:41-51

Gaucher C (2000) Sedimentology, palaeontology and stratigraphy of the Arroyo del Soldado Group (Vendian to Cambrian, Uruguay). Beringeria 26:1-120

Gaucher C, Boggiani PC, Sprechmann P, Sial AN, Fairchild T (2003) Integrated correlation of the Vendian to Cambrian Arroyo del Soldado and Corumbá Groups (Uruguay and Brazil): palaeogeographic, palaeoclimatic and palaeobiologic implications. Precambr Res 120:241-278

Gaucher C, Chiglino L, Pecoits E (2004) Southernmost exposures of the Arroyo del Soldado Group (Vendian to Cambrian. Uruguay): Paleogeographic implications for the amalgamation of W.Gondwana. Gondwana Res 7:701-714

Gaucher C, Finney SC, Poiré DG, Valencia VA, Grove M, Blanco G, Pamoukaghlián K, Gómez Peral L (2008) Detrital zircon ages of Neoproterozoic sedimentary successions in Uruguay and Argentina: insights into the geological evolution of the Río de la Plata Craton. Precambr Res 167:150-170

Gaucher C, Frei R, Chemale Jr F, Frei D, Bossi J, Martínez G, Chiglino L, Cernuschi F (2010) Mesoproterozoic evolution of the Río de la Plata Craton in Uruguay: at the heart of Rodinia? Int J Earth Sci (this volume)

Girardi VAV, Mazzucchelli M, Molesini M, Civetta L, Petrini R, Bossi J, Campal N, Teixeira W, Correia CT (1996) Petrology and geochemistry of the mafic dyke swarm of the Treinta Y Tres region, Northeast Uruguay. J SA Earth Sci 9:243-249

Goldstein SL, O’Nions RK, Hamilton PJ (1984) A Sm-Nd isotopic study of atmospheric dusts and particulates from major river systems. Earth Planet Sci Lett 70:221-236

Gross AOMS, Droop GTR, Porcher CC, Fernandes LAD (2009) Petrology and thermobarometry of mafic granulites and migmatites from the Chafalote Metamorphic Suite: new insights into the Neoproterozoic P-T evolution of the Uruguayan-Sul-RioGrandense Shield. Precambr Res 170:157-174

Hallinan S, Mantovani M, Shukovsky W, Braggion JrI (1993) Estrutura do Escudo Sulbrasileiro: uma revisão através de dados gravimétricos e magnetométricos. Revista Brasileira de Geociências 23:201-214

Halls HC, Campal N, Davis DW, Bossi J (2001) Magnetic studies and $\mathrm{U}-\mathrm{Pb}$ geochronology of the Uruguayan dike swarm, Rio de la Plata Craton, Uruguay: paleomagnetic and economic implications. J SA Earth Sci 14:349-361

Hartmann LA (1998) Deepest exposed crust of Brazil-Geochemistry of Paleoproterozoic depleted Santa Maria Chico granulites. Gondwana Res 1:331-341

Hartmann LA, Nardi LVS (1982) Os Granitos Santo Afonso, Saibro e Vauthier da regiao de Dom Pedrito, RS: geologia, petrografia e geoquimica de elementos maiores, com interpretacão geotectónica. Acta Geologica Leopoldensia 12:153-178
Hartmann LA, Leite JAD, Mc Naughton NJ, Santos JOS (1999) Deepest exposed crust of Brazil-SHRIMP establishes three events. Geology 27:947-950

Hartmann LA, Piñeyro D, Bossi J, Leite JAD, Mcnaughton NJ (2000) Zircon U-Pb SHRIMP dating of Paleoproterozoic Isla Mala granitic magmatism in the Rio de la Plata Craton, Uruguay. J SA Earth Sci 13:105-113

Hartmann LA, Campal N, Santos JO, McNaughton N, Bossi J, Schipilov A, Lafon JM (2001) Archean crust in the Río de la Plata Craton, Uruguay-SHRIMP U-Pb zircon reconnaissance geochronology. Journal South American Earth Sciences 14:557-570

Hartmann LA, Santos JO, Bossi J, Campal N, Schipilov A, McNaughton N (2002) Zircon and Titanite U-Pb SHRIMP geochronology of Neoproterozoic felsic magmatism on the eastern border of the Río de la Plata Craton, Uruguay. Journal South American Earth Sciences 15:229-236

Hartmann LA, Santos JOS, Leite JAD, Porcher CC, McNaughton NJ (2003) Metamorphic evolution and U-Pb zircon SHRIMP geochronology of the Belizário ultramafic amphibolite, Encantadas Complex, southernmost Brazil. Anais da Academia Brasileira de Ciências (Ann Braz Acad Sci) 75:393-403. ISSN 0001-3765

Hartmann LA, Bossi J, Santos JOS, Mc Naughton NJ, Piñeyro D (2008a) Geocronología SHRIMP U-Pb en circones del Gabro Rospide del Cinturón Paleoproterozoico San José, Terreno Piedra Alta, Uruguay: una prueba geocronológica de magmas coetáneos. Revista Sociedad Uruguaya de Geología 15:40-53

Hartmann LA, Liu D, Wang Y, Massonne H-J, Santos JOS (2008b) Protolith age of Santa Maria Chico granulites dated on zircons from an associated amphibolite-facies granodiorite in southernmost Brazil. Anais da Academia Brasileira de Ciências 80:543-551

Heinrichs H, Herrmann AG (1990) Praktikum der Analytischen Geochemie. Springer, Berlin $669 \mathrm{pp}$

Hoffman PF (1988) United Plates of America, the birth of a craton: early Proterozoic assembly and growth of Laurentia. Ann Rev Earth Plan Sci 16:543-603

Iacumin M, Piccirillo EM, Girardi VAV, Teixeira W, Bellieni G, Echeveste H, Fernandez R, Pinese JPP, Ribot A (2001) Early proterozoic calc-alkaline and middle proterozoic tholeiitic Dyke Swarms from Central-Eastern Argentina: petrology, geochemistry, $\mathrm{Sr}-\mathrm{Nd}$ isotopes and tectonic implications. J Petrol 42(11):2109-2143

Kay S, Orrell S, Abbruzzi JM (1996) Zircon and whole rock Nd-Pb isotopic evidence for a Grenville Age and a Laurentian origin for the basement of the Precordillera in Argentina. J Geol 104:637-648

Larin AM (2009) Rapakivi granites in the geological history of the earth. Part 1, magmatic associations with rapakivi granites: age, geochemistry, and tectonic setting. Stratigr Geol Correl 17:235-258

Loewy S, Connelly JN, Dalziel IWD, Gower CF (2003) Eastern laurentia in rodinia: constraints from whole-rock $\mathrm{Pb}$ and $\mathrm{UPb}$ geochronology. In: Sircombe KN, McElhinny MW (eds) Orogenic belts, regional and global tectonics: a memorial volume to Chris McAulay Powell. Tectonophysics 375:169-197

Loewy SL, Connelly JN, Dalziel IWD (2004) An orphaned basement block: the Arequipa-Antofalla basement of the central Andean margin of South America. Geol Soc Am Bull 116:171-187

Mallmann G, Chemale F Jr, Ávila JN, Kawashita K, Armstrong RA (2007) Isotope geochemistry and geochronology of the Nico Pérez Terrane, Rio de la Plata Craton, Uruguay. Gondwana Res 12:489-508

Marchese HG, Di Paola EC (1975) Reinterpretación estratigráfica de la Perforación Punta Mogotes $N^{\circ} 1$, Provincia de Buenos Aires. Revista de la Asociación Geológica Argentina 30:17-44 
Masquelin H (2004) El Complejo Cerro Olivo, Sureste de Uruguay: una revisión estratigráfica y tectónica. Actas IV Congreso Uruguayo Geología, CD-ROM, Montevideo

Masquelin H, Silva AOM, Porcher CC, Fernandes LAD, Morales E (2001) Geología y termobarometría de la Suite metamórfica Chafalote, Basamento pre-Brasiliano, Sureste del Uruguay. In: Actas XI Congreso Latinoamericano Geología. CD-ROM

Mazzucchelli M, Rivalenti G, Piccirillo EM, Girardi VAV, Civetta L, Petrini R (1995) Petrology of the Proterozoic mafic dyke swarms of Uruguay and constraints on their mantle source composition. Precambr Res 74:177-194

Oyhantçabal P (2005) The Sierra Ballena Shear zone: kinematics, timing and its significance for the geotectonic evolution of southeast Uruguay. http://webdoc.sub.gwdg.de/diss/2005/ oyhantcabal_cironi/oyhantcabal_cironi.pdf

Oyhantçabal P, Vaz N (1990) Una asociación de cuarcitas y rocas máficas y ultramáficas en los alrededores de Isla Patrulla, Treinta y Tres, Uruguay. In: Primer Congreso Uruguayo de Geología, vlo 1. Montevideo, pp 137-144

Oyhantçabal P, Muzio R, Derrégibus M, Nardi LVS (1998) The Soca intrusion: a rapakivi granite of Uruguay. Journal of South America Earth Sciences 11(2):169-178

Oyhantçabal P, Spoturno J, Aubet N, Cazaux S, Huelmo S (2003) Proterozoico del suroeste del Uruguay: nueva propuesta estratigráfica para la Formación Montevideo y el magmatismo asociado. Rev Soc Urug Geol Pub Esp 1:38-48

Oyhantçabal P, Sánchez Bettucci L, Pecoits E, Aubet N, Peel E, Preciozzi F, Basei MAS (2005) Nueva propuesta estratigráfica para las supracorticales del Cinturón Dom Feliciano (Proterozoico, Uruguay). XII Congreso Latinoamericano de Geología, Quito (CD-ROM

Oyhantçabal P, Siegesmund S, Wemmer K, Frei R, Layer P (2007a) Post-collisional transition from calc-alkaline to alkaline magmatism during transcurrent deformation in the southernmost Dom Feliciano Belt (Braziliano-Pan-African, Uruguay). Lithos 98:141-159

Oyhantçabal P, Spoturno J, Loureiro J (2007b) Caracterización geológica de las rocas Paleoproterozoicas de la región CentroSur del Uruguay (Terreno Piedra Alta-Cratón Del Río De La Plata). In: Actas V Congreso Uruguayo de Geología. CD-ROM

Oyhantçabal P, Siegesmund S, Wemmer K, Presnyakov S, Layer P (2009) Geochronological constraints on the evolution of the southern Dom Feliciano Belt (Uruguay). J Geol Soc 166:1075-1084

Oyhantçabal P, Suárez I, Seluchi N, Martínez X (2010) Análisis Microtectónico de las Milonitas del Extremo Sur de da Zona de Cizalla Sarandí del Yi: Cinemática y Condiciones de Deformación. In: Actas VI Congreso Uruguayo de Geología. CD-ROM

Pankhurst RJ, Ramos A, Linares E (2003) Antiquity and evolution of the Río de la Plata craton in Tandilia, southern Buenos Aires province, Argentina. J SA Earth Sci 16:5-13

Pecoits E, Aubet N, Oyhantçabal P, Sánchez Bettucci L (2004) Estratigrafía de Sucesiones Sedimentarias y volcanosedimentarias Neoproterozoicas del Uruguay. Revista Sociedad Uruguaya Geología 11:18-27

Pecoits E, Gingras M, Aubet N, Konhauser K (2008) Ediacaran in Uruguay: palaeoclimatic and palaeobiological implications. Sedimentology 55:689-719

Peel E, Preciozzi F (2006) Geochronologic synthesis of the Piedra Alta Terrane, URUGUAY. V South American Symposium on Isotope Geology. Punta del Este, Uruguay, pp 234-237

Philipp RP, Lusa M, Nardi LVS (2008) Petrology of dioritic, tonalitic and trondhjemitic gneisses from Encantadas Complex, Santana da Boa Vista, southernmost Brazil: Paleoproterozoic continentalarc magmatism. Anais da Academia Brasileira de Ciências (Ann Braz Acad Sci) 80:735-748. ISSN 0001-3765
Preciozzi F (1993) Petrography and geochemistry of five granitic plutons from south-central Uruguay. Contribution to knowledge of the Piedra Alta Terrane. PhD Thesis, Université du Québec, Quebec, 189 pp. http://dx.doi.org/doi:10.1522/1498484

Preciozzi F, Spoturno J, Heinzen W (1979) Carta geo-estructural del Uruguay, escala 1:2.000.000. Instituto Geológico Ing. Terra Arocena, Montevideo $62 \mathrm{pp}$

Preciozzi F, Spoturno J, Heinzen W, Rossi P (1985) Carta Geológica del Uruguay a escala 1:500.000, Dirección Nacional de Minería y Geología, Montevideo, $92 \mathrm{pp}$

Preciozzi F, Basei MAS, Masquelin H (1999) New geochronological data from the Piedra Alta Terrane (Rio de La Plata Craton). In: II South American Symposium on Isotope Geology, Córdoba, pp 341-343

Rapela CW, Pankhurst RJ, Casquet C, Fanning CM, Baldo EG, González-Casado JM, Galindo C, Dahlquist J (2007) The Río de la Plata Craton and the assembly of SW Gondwana. Earth-Sci Rev 83:49-82

Rivalentil G, Mazzucchellil M, Molesini M, Petrini R, Girardi VAV, Bossi J, Campal N (1995) Petrology of late proterozoic mafic dikes in the Nico Perez region, central Uruguay. Mineral Petrol 55:239-263. doi:10.1007/BF01165120

Saalmann K, Hartmann LA, Remus MVD, Koester E, Conçeição RV (2005) Sm-Nd isotope geochemistry of metamorphic volcanosedimentary successions in the São Gabriel Block, southernmost Brazil: evidence for the existence of juvenile Neoproterozoic oceanic crust to the east of the Rio de la Plata craton. Precambr Res 136:159-175

Saalmann K, Gerdes A, Lahaye Y, Hartmann LA, Remus LA (2010) Multiple accretion at the eastern margin of the Rio de la Plata craton-the prolonged Brasiliano orogenic cycle in southernmost Brazil. Int J Earth Sci (this volume)

Sánchez Bettucci L (1998) Evolución Tectónica del Cinturón Dom Feliciano en la región Minas-Piriápolis, República Oriental del Uruguay. Unpublished PhD Thesis, Universad de Buenos Aires, Buenos Aires

Sanchez Bettucci L, Oyhantcabal P (2008) Tectonic map of Uruguay. American Geophysical Union, Spring Meeting 2008, abstract \#S41B-05

Sánchez Bettucci L, Oyhantçabal P, Loureiro J, Ramos VA, Preciozzi F, Basei MAS (2004) Mineralizations of the Lavalleja group (Uruguay), a probable neoproterozoic volcano-sedimentary sequence. Gondwana Res 6:89-105

Sánchez Bettucci L, Peel E, Oyhantçabal P (2010) Precambrian geotectonic units of the Río de La Plata craton. Int Geol Rev $52: 32-50$

Santos JOS, Hartmann LA, Bossi J, Campal N, Schipilov A, Piñeyro D, Mc Naughton NJ (2003) Duration of the trans-Amazonian cycle and its correlation within South America Based on U-Pb SHRIMP Geochronology of the La Plata Craton, Uruguay. Int Geol Rev 45:27-48

Schumacher E (1975) Herstellung von 99, 9997\% 38Ar für die $40 \mathrm{~K} / 40 \mathrm{Ar}$ Geochronologie. Geochronologia Chimia 24:441-442

Schwartz JJ, Gromet LP (2004) Provenance of a late proterozoicearly Cambrian basin, Sierras de Córdoba, Argentina. Precambr Res 129:1-21

Sengör AMC (1999) Continental interiors and cratons: any relation? Tectonophysics 305:1-42

Slepp NH (2005) Evolution of the continental Lithosphere. Ann Rev Earth Plan Sci 33:369-393

Steiger RH, Jaeger E (1977) Subcommission on geochronology: convention on the use of decay constants in geo and cosmochronology. Earth Planet Sci Lett 36:359-362

Teixeira W, Renne PR, Bossi J, Campal N, D'Agrella Filho MS (1999) ${ }^{40} \mathrm{Ar}-{ }^{39} \mathrm{Ar}$ and $\mathrm{Rb}-\mathrm{Sr}$ geochronology of the Uruguayan dike swarm, Rio de la Plata Craton and implications for 
Proterozoic intraplate activity in western Gondwana. Precambr Res 93:153-180

Teixeira W, Pinese JPP, Iacumin M, Girardi VAV, Piccirillo EM, Echeveste H, Ribot A, Fernandez R, Renne PR, Heaman LM (2002) Calc-alkaline and tholeiitic dyke swarms of Tandilia, Rio de la Plata craton, Argentina: U-Pb, Sm-Nd, and $\mathrm{Rb}-\mathrm{Sr}{ }^{40} \mathrm{Ar} /{ }^{39} \mathrm{Ar}$ data provide new clues for intraplate rifting shortly after the Trans-Amazonian orogeny. Precambr Res 119:329-353

Todt W, Cliff RA, Hanser A, Hofmann AW (1993) Re-calibration of NBS lead standards using a202 $\mathrm{Pb}+205 \mathrm{~Pb}$ double spike. Terra Abstracts 5, Suppl. 1

Tosdal RM (1996) The Amazon-Laurentian connection as viewed from the Middle Proterozoic rocks in the central Andes, western Bolivia and northern Chile. Tectonics 15:827-842
Umpierre M, Halpern M (1971) Edades Sr-Rb del Sur de la República Oriental del Uruguay. Revista Asociación Geológica Argentina 26:133-151

Vidal H (2009) Estudio geológico-estructural del área de Cerro Papagayo, Isla Cristalina de Rivera-Uruguay. Unpublished Degree Thesis, Universad de la República, Montevideo

Wemmer K (1991) K/Ar-Altersdatierungsmöglichkeiten für retrograde Deformationsprozesse im spröden und duktilen BereichBeispiele aus der KTB Vorbohrung (Oberpfalz) und dem Bereich der Insubrischen Linie (N-Italien). Göttinger Arbeiten Geologie und Paläontologie 51:1-61 